XVI. Contributions to an Insect Fauna of the Amazon Valley (Coleoptera, Cerambycidæ). By H. W. Bates, F.Z.S., late Pres. Ent. Soc.

[Read 4th July, 1870.]

THE present memoir is a continuation of a former one on the Prionides (Trans. Ent. Soc. 1869, p. 37), and the classification, with trifling modifications, is that established by Lacordaire in the eighth and ninth volumes of his "Genera des Coléoptères."

Fam. CERAMBYCIDA.

Section A. Eyes coarsely facetted.

Sub-fam. Семіќж.

Antennæ without spines, anterior coxæ with their sockets lengthened externally, intermediate sockets open.*

\title{
Genus Atenizus.
}

Bates, Entom. Monthly Mag. iv. 28 (1867).

(Charac. emend.). Corpus parvum, sublineare, depressum, pubescens. Caput rotundatum, thorace latius, genis brevissimis, fronte convexa, vertice tuberculo magno instructo; oculis magnis emarginatis, lobo inferiori ante tuberculos antennarum producto, superiori brevi ; palpis articulo terminali conico, maxillaribus (?) elongatis, $\delta$ pendentibus. Antennæ filiformes, hirsutæ, articulo basali apice infra dilatato. Thorax ovatus, depressus, inermis. Elytra linearia, apice rotundata. Pedes breves, lineares, tarsis posticis elongatis. Coxæ anticæ et intermediæ subconicæ, contiguæ, exsertæ, acetabula antica extus angulata, intermedia aperta; laminæ sternales inter coxas obsoletæ.

This is one of the genera which M. Lacordaire was unable to place in the rigid system of classification

* That is, the mesothoracic epimera are inserted between the mesoand meta-thorax so far as to reach the orbit of the sockets.

TRANS. ENT. SOC. 1870. - PART III. (AUGUST.) 
adopted by him. On a careful examination, I have no doubt it belongs to his group Emides, and that its place would be probably in Section I. of that group. The angulation of the anterior sockets is not so strongly pronounced as in Eme and the other genera of the group; but this may be attributable to the narrow form of the prothorax. The sternal processes between the anterior and middle coxæ appear to be wholly wanting. The abdominal segments are normal, and not distorted as in the Obrioninae.

\section{Atenizus laticeps, Bates, l. c.}

"Sublinear, reddish-testaceous; antennæ from the third joint brown, bases of joints pale testaceous. Body and limbs finely setose; head and thorax sparingly punctured ; elytra regularly and closely punctured."

Long. $2 \frac{1}{2}-4 \frac{1}{2}$ lin. के $q$.

Hab.-Pará and Santarem, Amazons; on dry twigs.

\section{Genus Niophis.}

Bates, Entom. Monthly Mag. iv. 27 (1867).

(Charac. emend.). Corpus parvum, elongatum, lineare, depressum, pubescens. Caput postice haud angustatum, genis brevissimis, fronte concava; oculis magnis præcipue lobo inferiori, supra longe separatis; palpis apice truncatis; tuberculis antenniferis haud elevatis, vertice plano. Antennæ ( $\delta$ ) corpore multo longiores, longe pubescentes, articulis 3-5 longitudine subæqualibus. Thorax elongatus, inermis, à medio usque ad basin angustatus. Elytra postice attenuata, utrinque longe spinosa. Pedes elongati, femoribus valde elongatis, compressis, gradatim clavatis; tarsis articulo basali elongato. Coxæ anticæ exsertæ, conicæ, extus modice angulatæ, processu sternali angustissimo; acetabula intermedia extus aperta, processu sternali latiusculo plano. Abdomen (ठ) segmento basali cæteris haud longiori.

This genus is evidently allied both to Atenizus and Eme, and on this account, although unable to ascertain the texture of the ligula, I have no hesitation in placing it in the present group. The antennal joints are clothed all round with a long pubescence. The buccal aperture is close to the lower margin of the eyes, there being no muzzle. The eyes are emarginate, with well-developed upper lobe. 
1. Niophis coptorrhina, Bates, $l$. $c$.

Tawny reddish, opaque, clothed with fine erect hairs; apices of antennal joints darker, tips of thighs black; thorax with two broad and shallow longitudinal dorsal channels; elytra finely punctured, the apex of each with an acute spine.

Long. $4 \frac{1}{2}$ lin. $\delta$.

Hab.-Santarem, River Tapajos.

Genus Eme.

Newman, Entom. i. 8; Lacord. Gen. Col. viii. 222.

In this genus, the thorax (unarmed) is abruptly narrowed near the base, and the prosternal process is reduced to an extremely narrow vertical partition.

\section{Eme picticornis, n. sp.}

Elongata, linearis, depressa, pallido-fulva, antennarum articulis (a tertio) et tarsis nigris ; capite et antennarum articulo basali crebre et grosse punctato ; thorace subquadrato, basi subito constricto, dorso subtiliter creberrime punctato, sericeo ; elytris pube erecta tectis, crebre punctulatis, apice conjunctim rotundatis; (abdomen deest).

Long. 8 lin. 8 .

Apparently allied to $F$. annulicornis, Buq., which, however, is described as having the head smooth, and the thorax "en ovale très allongé." In the present species, the thorax, except the constricted hind portion, forms a square, almost exactly as broad as long, with the angles rounded. Besides the black tips of the antennal joints and the tarsi, the tergum of the mesothorax, uncovered by the base of the thorax, has a distinct black spot. The antennæ are regularly ciliate beneath, and have only a short pubescence above.

One example, taken at Ega, evidently a male.

\section{Genus Phrynocris.}

Bates, Entom. Monthly Mag. iv. 26; Lacord. Gen. Col. viii. 226 .

1. Phrynocris notabilis, Bates, $l$. c.

Body elongate, subdepressed. Head and thorax coarsely and scantily tomentose, the rest of the body clothed with

TRANS. ENT. SOC. 1870.-PART III. (AUGUST.) 
short hairs. Thorax subquadrate, armed on each side with a spine, surface uneven, covered with small scattered tubercles, reddish-tawny, with the depressed parts black. Elytra reddish-tawny, ornamented with three strongly undulated black belts, the apex also black; surface shining, punctured and roughened with three or four rows of small tubercles. Legs reddish, tips of thighs and tibiæ black.

Long. 10 lin. 8 .

Hab.-Ega.

\section{Genus Zathecus.}

Bates, Entom. Monthly Mag. iv. 26 ; Lacord. Gen. viii. 230 .

In addition to the characters given in the places quoted, may be here mentioned the sockets of the anterior coxæ angulate externally, and those of the intermediate coxæ open. These characters show that the genus is related to Eme. The markings of the elytra, however, are very similar to those of Ibidion, and allied genera. The thorax is subquadrate, narrowed behind and unarmed, slightly uneven above, without transverse impressions, and opaque; the thighs are elongate, and strongly and abruptly clavate.

\section{Zathecus graphites, Bates, l. c.}

Elongate, linear, depresseả. Testaceous, head and thorax clothed with a silky tomentum; vertex dusky, basal joints of antennæ blackish beneath. Thorax uneven, black, with a curved testaceous belt across the anterior part. Elytra near the base and suture marked with a black patch, followed behind by two curved black streaks; the testaceous apical half with a brownish cloud in the middle; whole surface roughened with small scattered tubercles, and irregular but not large punctures. Legs and under-surface testaceous, sides of prothorax and breast and basal part of hind thighs blackish.

Long. 8 lin. $\delta$.

Hab.-Ega. 
Genus Malacopterus.

Serville, Ann. Soc. Ent. Fr. 1833, p. 565; Lacord. Gen. viii. 227.

1. Malacopterus lineatus, Guérin, Icon. Règne Anim.

p. 222.

Elongatus, depressus, pallidus ; elytris utrinque brunneo bivittatis, thorace medio carinato, margine postico producto-lobato; antennis fortissimis $\left(\sigma^{\top}\right)$ apicem versus attenuatis.

Long. 10 lin.

Hab.-Pará.

Sub-fam. Achrysoninæe.

This sub-family differs from the Emince only in the anterior haunches being less angulate externally, with the sockets having a corresponding narrower and shorter opening on their outer side.

\section{Genus Achryson.}

Serville, Ann. Soc. Ent. Fr. 1833, p. 572 ; Lacord. Gen. viii. 232.

1. Achryson surinamum.

Cerambyx surinamus, Lin. Syst. Nat. ii. 632.

A widely-distributed and well-known insect, cylindrical in form, of pale reddish-testaceous colour, with a black circumflex mark on the posterior disc of each elytron, and a few smaller spots on the anterior part of the same.

Common throughout the Amazons; the earlier states are passed in the interior of certain trees having wood of a light texture, and the insect is often found in the neighbourhood of houses.

\section{Achryson nanum, n. sp.}

Parvum, lineare, rufo-testaceum, unicolor, corpore toto longe piloso ; thorace quam in A. surinamo longiori et magis cylindrico, creberrime subtiliter rugoso, tuberculis 
acutis subseriatis asperato, linea longitudinale et foveolis duabus disci anterioris impresso ; elytris asperato-punctatis, apicibus in dente lato sub-obtuso productis.

Long. $3 \frac{1}{2}$ lin. of (?).

$H a b$.-Tapajos.

\section{Achryson pictum, n. sp.}

Minus lineare, thorace subovato, postice angustato, rufum, sparsim breviter pubescens, thorace disco plagis confluentibus nigris ; elytris apice aculeatis, pallide brunneis, maculis magnis nigris, scilicet, una circa scutellum, altera obliqua elongata humerali, plaga triangulari discali pone medium, et una apicali; antennis pedibus et episternis nigris.

Long. $7 \frac{1}{2}$ lin.

Of shorter and less cylindrical form than A. surinamum : thorax shorter, more rounded on the sides, and attenuate from the middle to the base. Clothed with a moderate tawny pubescence, sub-erect on the elytra and legs ; colour red, varied with black patches, elytra yellower and shining, thorax opaque; antennæ, legs, and side-pieces of the sterna black. Head very coarsely rugose, thorax minutely rugose, and with scattered elevated granules; elytra punctured, more coarsely and densely so near the base. The black marks on the thorax are on the disc, and consist of a lateral vitta expanding on the front margin, and two central vittæ extending only from base to middle, and there united by a cross belt; but these marks are sometimes more or less blended. On the elytra the base is spotted with black, and there is a squarish black spot in the scutellar region, an oblique stripe from the shoulder, a triangular discal patch behind the middle, and a spot at the apex, including the apical spine.

Hab.-Pará; also found at Cayenne.

\section{Achryson hirsutulum, n. sp.}

Parvum, lineare, thorace medio paulo rotundato, elytris apice acutis, castaneum, fulvo-hirsutum; thorace et elytris pilis crassis decumbentibus, illo lineis tribus dorsalibus, his vittis irregularibus nudis; elytris coriaceis opacis, apice politis, basin versus sparse granulatis. 
Long. $4 \frac{1}{4}$ lin.

Allied to A. ornatipenne (Perroud) from Guadeloupe; but differing in the sculpture and apical armature of the elytra, besides the less regular arrangement of vittæ on the latter. According to Perroud's description, the elytra are " très faiblement tronquées à leur extrémité," whereas $A$. hirsutulum has the apex of each prolonged into an acute tooth, distinct enough, but not spiniform, as in A. surinamum. The pubescence is very coarse and decumbent on the body, but the elytra have besides erect setæ springing from the few acute granules on their surface.

Hab.-Tapajos.

Sub-fam. Torneutine.

Large robust insects with exserted and robust mandibles in the males, and a broad apex to the abdomen in both sexes.

\section{Genus Coccoderus.}

Buquet, Rev. Zool. 1840, p. 293 ; Lacord. Gen. viii. 243.

\section{Coccoderus amazonicus, n. sp.}

Elongatus, parallelogrammicus, rufo-testaceus, elytris (basi excepta) pallidis, maculis eburneis utrinque tribus : capite grosse punctato, genis infra oculos lobo subhamato productis, mandibulis magnis curvatis intus fortiter dentatis; thorace grosse rugoso-punctato, tuberculis atris nitidis, duobus dorsalibus, alteris duobus marginalibus, prope margines anticum et posticum arcte constricto ; elytris glabris nitidis, macula eburnea basali, altera discoidali paulo ante medium, alteraque post medium: antennis omnino inermibus.

Long. $13 \frac{1}{2}$ lin. $\delta$.

Although a true Coccoderus, this species differs from the definition of the genus given by Lacordaire, in not having the 3-5 joints of the antennæ spinose at the apex. It seems to approach nearest C. bisignatus, of Buquet, which, however, has only one ivory-like spot on each elytron. It differs from C. sexmaculatus of the same author, in the coarsely sculptured thorax.

Hab.-Tapajos ; one example. 
Sub-fam. Cerambycine.

Genus Hammaticherus.

Serville, Ann. Soc. Ent. Fr. 1834, p. 15; Lacord. Gen. viii. 255.

\section{Hammaticherus Batus.}

Cerambyx datus, Lin. Mus. Lud. Ulr. Reg. p. 69;

C. Batus, Lin. Syst. Nat. ii. 625 .

Omnino fusco-niger, tarsis palpisque solum fulvis; thorace rugis profundis non interruptis circiter decem transversis breviter cinereo-tomentosis; elytris pube brevissima cinerea vix punctulatis, apice recto truncato, utroque angulo longe spinoso; eorpore subtus et pedibus cinereo-tomentosis. Antennæ $\delta$ corpore triplo longiores, $q$ corpore paulo longiores; utroque sexu articulis 3-6 apice mucrone valido recurvo armatis.

Long. 1 un. 4 lin. -1 un. 7 lin. $\delta$ o .

The Linnæan name is sometimes applied to an allied but distinct species, from South Brazil, which has chesnut-coloured elytra, narrowly edged with black, and golden pubescence on the thorax.* The excellent original description of Linnæus, in which both thorax and elytra are described as fuscous, leaves no doubt which form he described; and besides, at the early date when his description was written, the Entomology of South Brazil was almost unknown in Europe, although large numbers of insects had been received from Surinam.

Hab.-Obydos, Guiana side of Lower Amazons.

The species was rare in the Amazons; found on the boughs of felled trees.

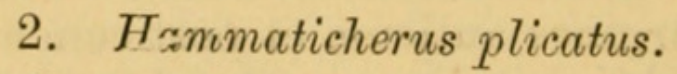

Cerambix plicatus, Olivier, Entom. No. 67, p. 40, pl. xviii. p. 136.

Corpus nigrum, cinereo-argenteo-sericeum; thorace rugis profundis transversis paulo undulatis circiter de-

* This species may be thus defined:-

\section{Hammaticherus castaneus.}

H. Bato maxime affinis, corpore piceo, subtus cinereo-tomentoso, capite nigro, thorace aureo-tomentoso, rugis profundis circiter 10 transversis, elytris castaneis, cinereo-pubescentibus, vix nitidis, marginibus omnibus nigro-fuscis, apice truncatis utrinque bispinosis.

Long. 1 un. 9 lin. $\delta$.

Hab.-Brazilia. 
cem ; elytris rufo-castaneis opacis sericeis, nigro marginatis. Antennæ $\delta$ corpore sesqui longiores, articulo basali apice infra tuberculo acuto armato, articulis $3-10$ apice spinosis, 우 similes sed paulo breviores.

Long. 1 un. 3 lin. $\delta$.

Hab.-Amazons; generally distributed.

\section{Hammaticherus glabricollis, n. sp.}

Brevior, niger, nitidus, subtus (cum pedibus) cinereo leviter tomentosus; capite glabro, grosse punctato; thorace rugis -latioribus circiter 10 subinterruptis fundo sparsim punctatis, omnino glabro ; elytris apice angustioribus, truncatis, bispinosis, spina suturali multo breviori, supra crebre punctulatis punctis majoribus interspersis, fulvo-castaneis nigro-marginatis. Antennæ $\delta$ corpore sesqui longiores, articulo 4to precedente dimidio breviori, articulis $5-10$ apice infra productis, acutis haud spinosis.

Long. 8 lin. $\delta$.

Hab.-Ega; one example only.

\section{Hammaticherus macrus, n. sp.}

Magnus, thorace parvo, spinis lateralibus obtusis ; elytris amplis, medio leviter dilatatis, apicem versus rotundatis, prope suturam oblique truncatis et bidentatis; omnino cinnamomeus fulvo-tomentosus; oculis supra distantibus; tuberculis antenniferis supra dentatis, antennis $(q)$ corpore multo brevioribus, articulis $3-10$ apice infra mucronatis vel dentato-productis; thorace rugis medianis interruptis; elytris subopacis, subtiliter punctulatis.

Long. 2 un. $q$.

Of much less cylindrical form than the other species ; head narrower than the thorax, and the latter only half the width of the elytra. The elytra are far from being parallel sided, and are somewhat dilated about the middle of their length; and broadly rounded towards the apex; in consequence of this form, the apical truncature is confined to a small portion of the apical margin near the suture, and the exterior spine is placed about the middle of the apex; the sutural spine is very small. The colour of the 
entire insect is that of cinnamon, a little more ruddy (and rather shining) on the antennæ and legs. Only those rugæ of the thorax are regular which lie near the anterior margin, the rest are much interrupted, and the interstices are here and there thickened; the lateral spines are reduced to smallish conical tubercles. The antennæ are much shorter than the body, the apices of all the joints from 3-10 are produced and acute, but only the third and fourth are really spinous.

The species seems allied to H. bellator of Serville, which I have not seen; but it differs in colour and in several points of structure. The anterior haunches and their sockets are much angulate externally, as according to Lacordaire they are in $H$. bellator.

Hab.-Villa Nova (now Villa Bella), Amazons; one example.

\section{Genus Criodion.}

Serville, Ann. Soc. Ent. Fr. 1833, p. 571 ; Lacord. Gen. viii. 270 .

\section{Criodion torticolle, n. sp.}

Magnum, parallelogrammicum, depressum, castaneum, fulvo-griseo dense subtiliter tomentosum; capite vix punctato; antennis ( 9 ) tomentosis, infra ciliatis, supra basin versus setis raris vestitis, articulis apice nullomodo angulatis ; thorace quadrato, supra valde inæquali, sulcis brevibus flexuosis torto, lateribus foveolis nonnullis profundis nigris; elytris coriaceis, apice rotundatis, sutura spinosis; femoribus et tibiis intermediis et posticis apice valde spinosis.

Long. 2 un. 4 lin. $q$.

Closely allied to the type of the genus, C. tomentosum, Serv., differing chiefly in the very irregular surface of the thorax, which resembles a cerebral surface in its convoluted elevations and fissures. The antennal joints 5-8 have not their apical inner angles produced, and the antennæ are much less setose altogether than in most of the allied species.

Hab.-Pará. 


\section{Criodion rhinoceros, n. sp.}

Magnum, parallelogrammicum, vix depressum, fuscum, fulvo-griseo-tomentosum ; mandibulis suprà medio utrinque cornu valido acuto armatis; thorace transversim quadrato, supra inæquali, plagis elevatis nonnullis politis sulcisque rectis et curvatis; elytris subtilissime coriaceis, vermiculato-rugosis, apice truncatis et utrinque bispinosis; pedibus robustis, femoribus intermediis et posticis apice bidentatis.

Long. 2 un. $\delta$.

Notwithstanding the very remarkable armature of the mandibles, this species is evidently a true Criodion, all other parts of structure agreeing with the typical species of the genus. The horn-like processes arise from the upper edge of the organs about the middle, are nearly as long as the mandibles themselves, and incline towards each other, crossing at the apices; together with the broal corrugate cheeks, they give to the head of the insect, viewed in profile, a curious resemblance to that of a Rhinoceros. The thorax is relatively much broader than in other species, and the irregular surface is marked in the middle with grooves forming a large trilobed figure, with the lobes directed towards the head.

Hab.-River Tapajos. I beat an example out of a tree in the forests near the mouth of the Tapajos, in 1852.*

\section{Genus Sphallenum, nov. gen.}

This genus is formed for the reception of certain species allied to Criodion, which differ from that group in having the sockets of the intermediate haunches

* The following is an undescribed species of Criodion, differing in the nearly-smooth thorax from the more typical forms :-

\section{Criodion hirsutum.}

Elongatum, angustatum, fuscum, fulvo-griseo-hirsutum, pilis thoracis et elytrorum decumbentibus. Caput rugosum, vertice inter oculos tuberculo elongato. Thorax quadratum, lateribus paulo rotundatis et rugosotuberculatis, dorso sublævi, punctis grossis et tuberculis lævibus tribus notato. Elytra creberrine punctulata, apice rotundata, sutura solum spinosa, supra pilis sparsis decumbentibus vestita. Femora intermedia et postica apice unispinosa, tibiis apice extus valde spinosis. Acetabula intermedia extus paulo hiantia.

Long. 1 un. 7 lin.; lat. elytr. $4 \frac{1}{2}$ lin.

Hab.-Bahia (a Dom. Reade captum). 
closed exteriorly. The closure is not produced by the elongation of the outer branch of the mesosternum to meet the corresponding part of the metasternum, but by a small prominence or tubercle at the anterior edge of the latter. The form of body is more cylindrical, and the derm more naked than in Criodion, and there is a striking difference in the antenniferous tubercles, which are contiguous to each other, and form, in fact, a short transverse bicuspid ridge between the roots of the antennæ. The intermediate tibiæ have a spine externally at their apices, which character distinguishes the genus from Xestia, where the tibiæ are unarmed.

I believe Cer. setosus, of Germar, belongs to this genus.

\section{Sphallenum puncticolle, n. sp.}

Elongatum, subcylindricum, nigro-fuscum, sparse setosum, antennis thorace scutello lateribusque pectoris fulvo-griseo-tomentosis; thorace punctis magnis discretis impresso; elytris castaneis, subtilicer punctulatis, apice utrinque bispinosis, femoribus medio rufo-castaneis.

Long. 1 un. 2 lin. -1 un. 8 lin. 8 우.

Differs from the following species in the separated punctures of the thorax, and in the dense and fine tomentose clothing of the same member. I should have taken it to be the Criodion castanopterum of Erichson, if there had been any allusion in that author's description to the tomentose thorax. It is also allied to Sph. setosus, of Germar ; but differs in wanting the erect yellow hairs on the elytra, mentioned in that author's description, and in the red femora. The elytra have only very minute, almost microscopic bristles in the punctures.

Hab.--Upper and Lower Amazons; generally found in repose on the leaves of trees in the forest.

\section{Sphallenum femorale, n. sp.}

Criodion castanopterum, Erichson, in Schomburgk's Reise, iii. 572 (?).

Elongatum, subcylindricum, nigro-fuscum, sparse setosum, antennis scutello lateribusque pectoris fulvo-griseo- 
tomentosis; thorace nudo, grosse et confuse rugosopunctato ; elytris castaneis, subtiliter punctulatis, apice utrinque bispinosis; femoribus medio læte rufis.

Long. 1 un. 2 lin. -1 un. 6 lin. of $q$.

Agrees with Erichson's description of Criodion castanopterum in all points, except the broad clear red ring round the middle of all the femora. It is possible, therefore, that Erichson's species may form a third and distinct one of this group.

Hab.-Upper and Lower Amazons ; in the same situations as S. puncticolle.

\section{Sphallenum tuberosum, n. sp.}

Minus elongatum et vix convexum, nigro-fuscum, glabrum, nitidum, antennis scutello lateribusque pectoris leviter tomentosis; capite thoraceque impunctatis, hoc tuberibus magnis circa 13 notato, toto lævi, polito; elytris vix punctulatis, apice utrinque bispinosis; pedibus piceo-rufis, femoribus medio et apice tibiisque basi fuscis exceptis.

Long. 1 un. 2 lin.

Hab.-Tapajos.*

\section{Genus Xestia.}

Serville, Ann. Soc. Ent. Fr. 1834, p. 16 ; Lacord.

Gen. viii. 271.

Restricted to those species which have the intermediate sockets quite closed, and the middle and posterior femora and tibiæ without spines at the apex.

* Criodion erythropus (Lucas, in Voy. de Casteln. p. 187, pl. xi. f. 6), from South Brazil, will, according to the views of Lacordaire (Gen. viii. 271 , note), which I have here adopted, require to be separated from Criodion, on similar grounds to those on which Sphallenum is instituted. The genus may be termed Butherium, with the following characters:-

\section{Butherium, nov, gen.}

Corpus oblongum, nudum. Caput tuberculis antenniferis basi late separatis; antennis articulo 4to (utroque sexu) haud 5to breviori. Femora apice simplicia, tibiis intermediis et posticis apice extus spinosis. Acetabula intermedia anguste hiantia.

Type. B. erythropus, Lucas, loc. cit. 
$X$. spinipenni (Serv.) proxime affinis; differt colore piceo-nigro polito; capite ut in $X$. spinipenne pone oculos constricto ; antennis ( $\delta$ ) corpore paulo brevioribus, articulo primo apice intus producto-angulato, 5-11 valde serratis, ultimo precedenti triente longiori et fere diviso apud divisionem angulatim producto; thorace grossissime sparsim punctato, dorso punctis in rugis transversis sitis, plaga mediana lævi ; elytris longe bispinosis, supra piceo-nigris, unicoloribus nitidis, haud coriaceis, subtilissime sparsim punctulatis; femoribus pectore abdomineque (partim) rufo-piceis.

Long. 11 lin. $\delta$.

Hab.-Pará.

2. Xestia brevipennis, n. sp.

$X$. spinipenni (Serv.) affinissima, corpore (præcipue elytris) distincte breviore robustiore; nigro-picea, elytris obscure castaneis, distincte coriaceis, subsericeo-opacis, passim punctulatis; capite cum tuberibus antenniferis grosse punctatis ; thorace latiori, antice minus angustato, lateribus rectioribus, antice subito constrictis, supra grossissime irregulariter rugoso-punctatis ; pedibus rufopiceis, femoribus apice fuscis; antennis ut in $X$. spinipenne ( $\delta$ ) corpore multo brevioribus, articulo basali apice rotundato.

Long. 1 un. के $q$.

Hab.-Ega.

3. Xestia glabripennis, n. sp.

Subcylindrica, castanea, polita ; capite parvo, oculis haud prominentibus; thorace transversim strigoso, disco postice lævi ; elytris flavo-castaneis, vix punctulatis, glaberrimis, apice bispinosis; femoribus clavatis; pectoris lateribus tenuiter fulvo-sericeis, mesosterno tuberculatio.

Long. 8 lin. 우.

Hab.-Tapajos. 
Distinguished from $X$. spinipennis, Serv., by the small size of the head, and the peculiarly flattened eyes, besides its glabrous integument. The sculpture of the thorax is also entirely different, consisting of a number of distinct and rather fine transverse furrows, which cover the whole surface, leaving only a small space on the hinder part of the dise smooth.

\section{Xestia ochrotania, n. sp.}

Oblongo-linearis, vix convexa, nigra, elytris castaneis, vitta utrinque ochracea ab angulo humerali usque ad apicem extensa, antice intus solum angustata.

\section{Long. 1 un. 2 lin. $q$.}

Belongs to a group of species of less cylindrical form than $X$. spinipennis and its allies, and having much less robust antennæ without perceptible difference in length between the fourth and fifth joints. They agree, however, in the closure of the intermediate sockets, and in the spineless apices of the hinder femora and tibiæ, and are, moreover, connected with the typical forms by species showing all the intermediate gradations.

$X$. ochrotcenia is closely allied to X. lateralis, Erichs.; judging from the description, there is no difference between them, except the mode in which the yellow vitta is narrowed to the humeral angle. Erichson's words are "vitta laterali antice extus abrupte, intus sensim attenuata." In X. ochrotoenia the vitta shows the inner gradual narrowing, but the outer edge is perfectly straight. The head and thorax are coarsely punctate-rugose, or scabrous; the elytra are finely coriaceous and punctulate, the apex is rounded, and there is a small spine only at the sutural angle. The ochreous vitta forms a welldefined moderately broad stripe, of equal width throughout, except the narrowing near the base, and not quite touching either the base or the apex; it is moderately distant from the lateral margin, and curves slightly towards the sutural angle. The sides of the elytra near the base have a depressed space rather more distinctly sculptured than the rest of the surface.

Hab.-Upper Amazons. 


\section{Genus Melathemma, gen. nov.}

Xestice affinis, sed antennis gracilibus, filiformibus, elongatis. Oculi magni, lobis inferioribus tubera antennifera superantibus, his valde obtusis sulcatis; collo haud constricto. Antennæ graciles, filiformes, corpore (ठ) multo longiores, glabræ, sparsim setosæ; articulo basali brevi, oblongo, tertio elongato, 4 to et 6 to precedenti brevioribus subæqualibus, cæteris æquilongis, $11 \mathrm{mo}$ duplo longiori excepto. Thorax inermis, subquadratus. Elytra subcylindrica, apice inermia. Prosternum arcuatum, acetabula extus angustissime emarginata; mesosternum planum, acetabula intermedia anguste aperta. Abdomen glabrum, apicem versus attenuatum. Pedes breves, inermes, femora compressa subclavata, tarsi articulo primo 2ndo 3ioque conjunctim breviori. Corpus subcylindricum, politum, sparse hirsutum.

This genus is formed for the reception of a species which is closely allied to Xestia in its principal characters, but differs greatly from it in facies, and in the long slender filiform and non-tomentose antennæ, which, in the male (the only sex I know), are longer by one-half than the body, and have a short oblong (not conical) basal joint. The head is not constricted behind the eyes, the antenniferous tubercles are very obtuse, the upper edges being rounded; and they are separated from each other at their bases by a narrow portion of the forehead. The thorax is scarcely broader than the head, and of subquadrate outline, glabrous, with fine transverse striæ. The elytra are quite unarmed at the apex.

\section{Melathemma polita, n. sp.}

Subcylindrica, nigra, polita, sparsim griseo-hirsuta; elytris vittulis duabus ochreis vel omnino nigris punctatis ; scutello tomento griseo fimbriato; thorace transversim subconfluenter rugoso, disco tri-tuberculato, tuberculo mediano elongato, lateralibus rotundis.

Long. $9 \frac{1}{2}$ lin. $\delta$.

Of the two male examples which I obtained of this species, one is wholly of a glossy deep black colour, and the other has on each elytron two short ochreous vittæ, one very short and linear near the middle of the disc, 
and the other much longer on the posterior part of the elytron. The antennæ are of a shining black, or pitchyblack throughout, fringed beneath with longish hairs in their basal part, and rather more densely clothed with hairs in their apical portion. The elytra are naked and glossy, except near the base, where there are numerous very long, gray, erect hairs. The body beneath is very glossy, except the sides of the meso- and meta-sternum, which are finely tomentose. The elytra are rather thickly punctured throughout.

Hab.-Ega.

Sub-fam. HeSPEROPHANIN ж.

Genus Hesperophanes.

Mulsant, Col. de France, Longic. p. 66 ; Lacord. Gen. viii. 275.

1. Hesperophanes amazonicus.

Obrium Amazonicum, White, Cat. Longic. Brit. Mus. p. 240.

Oblongo-linearis, fusco-castaneus, passim griseo-pubescens; capite exserto thoraceque subcylindrico rugosopunctatis; elytris punctatis, linea indistincta elevata; antennis articulo 3io triente 4 to longiori.

Long. $5 \frac{1}{2}-8$ lin. $\delta^{\pi}+$.

I do not know on what grounds Mr. White placed this species in the genus Obrium, to which it bears very little resemblance. All the characters are those of the typical Hesperophanes, with the exception that the head is more exserted, with a more convex neck, and the thorax more elongate. The thorax is, however, essentially of the same form as in Hesperophanes, being dilated and rounded at the sides anteriorly. The whole insect is of a reddish-brown colour, and covered with rather coarse erect grayish pubescence; the elytra are uniformly punctured, with a faint raised line from shoulder to apex; the head and thorax are coarsely rugose-punctate, or scabrous. The abdominal segments are normal in both sexes; the apical ventral plate being truncate in the $\delta$, and rounded in $q$. The antennæ are of the length of the body in the $\delta$, and two-thirds the length in the q, with the third joint about one-third longer than the fourth, and much shorter than the fifth.

Hab.-Santarem; taken flying into houses at night. 


\section{Genus Anoplomerus.}

Thomson, Classif. des Ceramb. p. 249 ; Lacord. Gen. viii. 279.

Anoplomerus gracilis, n. sp.

Cylindricus, rufo-testaceus; thorace rotundato-ovato, linea abbreviata discoidali elevata nigra; elytris utrinque maculis eburneis duabus geminatis fusco-cinctis, una paulo ante medium, altera inter medium et apicem, - maculaque fusca ad angulum suturalem; pedibus præcipue femoribus elongatis. .

Long. 6 lin. $\delta$.

Apparently closely allied to A. globulicollis (Buquet), but very much smaller. Head opaque, sometimes with a black spot on the occiput; thorax ovate, with sides equally rounded, surface opaque, owing to the minute sculpture, centre with a short elevated line covered by a black spot. Scutellum black. Elytra linear, of same width as the thorax; apex narrowly sinuate-truncate, with each angle of the truncature briefly spinous; surface granulate-punctate, with an erect dark bristle arising from each puncture, the sculpture much weaker near the apex; each elytron has two geminate elevated ivory spots, one at one-third, the other at two-thirds the length, and both encircled by a dusky ring; each spot is divided into two by a line of coarse punctures, and the inner portion is shorter than the outer; the latter, also, is more elevated, forming part of an elevated line extending down the elytron. There is a dusky spot within the sutural apex, which is connected by means of an indistinct dusky line with the dark ring of the posterior ivory spot. The legs are elongate, especially the femora, the posterior pair extending much beyond the apex of the elytra; the knees are black.

Hab.-River Tapajos; also Cayenne.

\section{Anoplomerus brachypus, n. sp.}

Elongatus, testaceo-rufus ; thorace oblongo-ovato, grosse punctato, maculis quatuor nigris transversis alteraque utrinque ad marginem anticum; elytris apice unispinosis, maculis eburneis elongatis utrinque tribus, 
una basali, alteris duabus paulo post medium; pedibus brevibus, robustis.

Long. 8 lin. $\delta$.

Of less cylindrical form than the preceding, the elytra tapering towards the apex, and each prolonged there into an elongate black spine; the thorax is oblong, rounded in the middle, and very closely covered with large punctures, or foveæ, giving a reticulate appearance; lying across the middle are four black spots, beside one on each side on the anterior margin. Elytra coarsely punctured, and with minute punctures on the interstices between the larger ones; setose, the apical third nearly smooth and shining; the basal eburneous spot is large and oblong, bordered with black behind; the two posterior spots consist of a smaller inner one, and a much larger outer one, the smaller a little in advance of the other, and separated distinctly from it; they are edged with black before and behind. The legs are short and stout, the hind femora not reaching, by a long way, the apex of the elytra; the knees are black.

This very distinct species occurred only at Pará.

\section{Genus Opades.}

Lacordaire, Gen. viii. 288.

\section{Opades vittipennis, $\mathrm{n}$. $\mathrm{sp}$.}

Elongatus, cinnamomeo-fuscus, pube subtili sericea vestitus; elytris oblongis, vix convexis, suturâ et vittis utrinque tribus obscurioribus notatis.

Long. 1 un. 3 lin. $\widetilde{\sigma}$.

Differs from $O$. costipennis, according to the descriptions of Buquet and Lacordaire, in its broader and less cylindrical form, and in the colour of its fine dense pubescence, which in O. costipennis is "greenish-gray," and in our species is of a dingy brown, or cinnamonbrown hue. Both species have two elevated and almost spiniform black tubercles on the disc of the thorax. The dark vittæ of the elytra lie along the interstices of the costæ, and are distinctly seen only in certain lights.

Hab.-Ega. 


\section{Genus Chlorida.}

Serville, Ann. Soc. Ent. Fr. 1834, p. 31; Lacord. Gen. viii. 289.

\section{Chlorida festiva.}

Cerambyx festivus, Lin. Syst. Nat. ii. 623.

This common and well-known tropical American insect is generally distributed throughout the Amazons region. I found it frequently at night, especially at sugar smeared on palings to attract moths.

\section{Chlorida curta.}

Thomson, Archives Entomologiques, i. 288.

Similar to Chl. festiva; but different in the markings of the thorax, and in the distinct sharply-elevated costæ of the elytra, especially the lateral one, which extends from the humeral callus to near the apex, where it joins the two inner ribs. The antennæ are black, with the basal joint red. The upper surface of the head is black. The thorax is dark red, with a very broad vitta on each side, and a central spot or stripe, very much wider on the fore margin than on the hind, black; the surface of the thorax is uneven and coarsely sculptured, as in Chl. festiva. The elytra are somewhat shorter relatively than in $C h l$. festiva, and besides the strong elevation of the ribs, offer a differential character in the thick punctuation of all the basal portion. Body beneath and legs red.

Long. 10 lin. 우 .

The species offers a very remarkable feature, unnoticed by its original describer, in the apex of the abdomen (in the of at least) being greatly dilated and swollen; the edge of the last ventral segment is straightly truncate, but the pygidium, or last dorsal segment, is rounded, slightly sinuate in the middle and on each side. This feature forms the chief character of Lacordaire's " Groupe Torneutides;" and it is a further instance of the instability of diagnostic characters in the Longicornia, that an isolated member of a distinct group should show it in so high a degree of development.

$$
\text { Hab.-Ega. }
$$


3. Chlorida fasciata, n. sp.

Angustata, capite thoraceque supra fusco-olivaceis, grosse punctatis ; elytris viridibus, basi fasciaque dentata obliqua ante medium flavis.

Long. 8 lin. $\delta$.

Narrower than Chl. festiva. Head and thorax above dark olive-brown, coarsely punctured. Antennæ black, with joints one and two, and the base of the third, pitchyred. Elytra glaucous-green, with a spot in the middle of the base, and an oblique belt of spots, beginning in a long line from the shoulder and terminating on the suture before the middle, pale yellow; the costr are three in number on each elytron, the two inner alone united before the apex. Body beneath, and legss, red; prothorax with a dusky belt before the coxæ.

Allied to Chl. denticulata, Buq., differing in the situation of the yellow marks of the elytra.

Hab.-St. Paulo, Amazons.

Sub-fam. EвURIIn ж.

Genus Styliceps.

Lacordaire, Gen. viii. 291.

1. Styliceps sericatus.

Ceragenia sericata, Pascoe, Trans. Ent. Soc., 2 ser., v. 16 (1858).

Ceragenia amazonica, Thoms. Classif. des Ceramb. p. 210 (1860).

Styliceps sericans, Lacord. Gen. viii. 292, note (1869).

"Læte rufo-fulvus, vix nitidus, prothoracis tuberculis disci, elytrorum apice summo, femorumque spinis apicalibus nigris; pectore abdomine elytroque singulo vittis duabus longitudinalibus aureo-sericeis." (Lacord.)

Long. 1 un. -1 un. 2 lin. $\delta$ o .

Distinguished from the genus Ceragenia, to which it bears a great general resemblance, by the sectional character of the coarse granulation of the eyes. The thorax is glossy red, with deep transverse furrows in front and 
behind, and the intermediate space covered with rounded smooth tubercles, two of which, in the middle, are black. Both sexes have the elevated tubercle on the crown which has suggested the name of the genus.

Hab.-Upper Amazons; also Cayenne.

\section{Genus Eburia.}

Serville, Ann. Soc. Ent. Fr. 1834, p. 8; Lacord. Gen. viii. 293.

\section{Eburia longicollis, n. sp.}

Elongata, angustata, fulvo-ochracea ; thorace angustato, lateribus acute spinosis (antice haud tuberculatis), disco tuberculis duobus elevatis conicis acutis nigris, supra haud profunde punctato-rugoso, rugis undulatis transversis; elytris fortiter punctatis, vitta prope suturam minute rugoso-punctata opaca, tertia parte apicali lævi, subtiliter flavo-pubescentibus cum setis longioribus nonnullis ejusdem coloris, maculis eburneis duabus elongatis geminatis, una basali, altera apud medium, antice et postice nigro-marginatis, apice bispinosis; pedibus elongatis, femoribus linearibus, apice nigris, intermediis et posticis longe unispinosis.

Long. 10 lin. q.

Resembles the species of Eburodacrys in form, and in the elongate femora, but has no trace of the groove along the third and fourth antennal joints, which is the chief character that distinguishes Eburodacrys from Eburia. The sculpture of the thorax consists of large shallow punctures, forming on the disc short very irregular transverse furrows. The elytra have the basal two-thirds thickly covered with circular punctures or foveoles, but near the suture these are replaced by a minute sculpture, rendering that part opaque, the apical third is smooth, or with very slight punctuation; the pubescence is fine, and of a golden yellow, with a few scattered longish bristles of the same colour; the apex only is glossy; the ivory spots are somewhat elongate, and the pairs of which each consist do not differ notably in relative length.

The species is evidently allied to the true E. 4-maculata of Linnæus, which, however, according to the description in the "Systema Naturæ," is destitute of the lateral thoracic spines.

Hab.-Ega. 


\section{Eburia costulata.}

Elongata, depressa, fusco-cinnamomea, flavo-griseo tomentosa ; thorace haud distincte punctato, transverso, depresso, sex-tuberculato, tuberculis duobus utrinque lateralibus duobusque disci, omnibus nigris et subæque conicis ; antennis rufescentibus, infra usque ad apicem densissime ciliatis; elytris punctatis et utrinque bicostulatis, apice longe unispinosis, maculis eburneis duabus geminatis, una basali minus elongata et æquali, altera pone medium majori et inæquali macula externa multo majori ; pedibus rufo-flavis, femoribus apice fuscis, intermediis et posticis bispinosis, spinis interioribus paulo longioribus.

Long. 11 lin. $\delta$.

Distinguished by its depressed form, and the two distinct costr of the elytra, which pass through the ivory spots, but do not reach the apex; the latter with only one elongate spine. The colour is a light tawnybrown, with the antennæe and legs rather yellower; the antennæ are remarkable for the long and dense fringe of hairs which extends nearly to the apex; the rest of the antennæ has a shorter pile. The thorax is depressed, without punctures apparent through the rather close ashy tomentum; the two lateral tubercles, that of the middle and that near the anterior angle, and the two tubercles on the disc, are all black and nearly equally prominent. The twin spots composing the basal spot of the elytra are similar in form, the exterior a little the longer; but the middle spots are very unequal; they are level on their front edge, but behind, the exterior one passes the other by one-third its length, and they are edged with black at both ends.

Hab.-Ega.

\section{Eburia unicolor, n. sp.}

Elongata, subcylindrica, rufescens, pube tenui fulva vel aureo-fulva vestita; antennis articulo basali antice sulcato; vertice tuberculo obtuso erecto ; thorace transverso, aureo-tomentoso, supra et infra foveolis grossis insculptis, dorso tuberculis obtusis duobus, lateribus utrinque bituberculatis, tuberculis omnibus concoloribus; elytris passim punctulatis, absque maculis eburneis, lateribus anguste nigro-marginatis ; pedibus rufis, femoribus intermediis et posticis apice bispinosis. Antennis $\delta$ articulo $11 \mathrm{mo}$ penultimo sesqui longiori.

Long. 1 un. -1 un. 4 lin. $\delta$ क 9 . 
Distinguished from all other Eburice as yet described by the total absence of ivory-like spots from the elytra. A small oblong smooth callus, which exists in the middle of the basal margin, may be taken as the sole vestige of these characteristic spots, but this is rufous, like the rest of the elytra. The insect is, nevertheless, a true Eburia, and is, in fact, very closely allied to the common E. octoguttata (Germ.) of South Brazil, having the same coarse punctuation or pitting of the surface of the thorax, and a similar but rather more elevated tubercle on the crown of the head, like the genus Styliceps.* The

* Eburia octoguttata exists in some collections under the name of $E$. didyma of Olivier. This must be wrong, as Olivier's insect, according to his description, has no lateral spines to the thorax, like E. 4-maculata of Linnæus, and is probably a West Indian species. A fine undescribed species of the octoguttata group is the following:-

Eburia maculicornis, n. sp.

Robusta, elongata, postice attenuata, supra minus convexa. Caput nigricans, fulvo-tomentosum, vertice tuberculo elevato obtuso. Antennæ (ठ) corpore duplo longiores, dimidio basali infra griseo-ciliatæ; condylis rufis, articulo basali antice sulcato, nigro, apice extus macula rufa, 2 ndo nigro, cæteris testaceo-rufis, apice nigris. Thorax transversus, nigricans, fulvo-tomentosus, supra grosse punctatus, tuberculis duobus minus elevatis, lateribus medio unispinosis. Elytra postice gradatim attenuata, apice truncata et bispinosa ; supra dorso deplanata, apud latera declivia, fere lævia, fulvo breviter pubescentia, maculis parvis flavis vix elevatis, haud eburneis, utrinque quatuor, apud basin duabus discretis, externa minori, alteris duabus paulo pone medium etiam discretis, interna minori. Pedes rufo-testacei, validi, femora compressa, apice nigra, intermedia et postica bispinosa.

Long. 1 un. 3 lin. $\delta$.

Hab.-Brazilia merid.

Another undescribed species differs from all others known to me in the peculiarly short and thick basal joint of the antennæ. I name it after the skilful Entomological traveller, Mr. Rogers, who has recently discovered it in South Brazil.

\section{Eburia Rogersi, n. sp.}

Elongato-oblonga, capite thoraceque vix elytris angustioribus; fulvorufa, elytris pallidioribus. Caput genis infra productis subspinosis; tuberibus antenniferis apice extus acutis, productis. Antennæ ( $\delta$ ) corpore duplo longiores, infra longe ciliatæ, articulo basali brevi, crasso, basi extus dilatato, subauriculato, antice concavo, articulo 3io supra subcanaliculato. Thorax transversus, grosse et dense punctatus, supra tubereulis nigris duobus elevatis, lateribus spina mediana rufa. Elytra opaca, passim punctata, breviter setosa, bicostulata, apice bispinosa, spinis nigris, externa multo longiori; supra macula flava eburnea elongata basali, haud elevata, extus et postice nigro-marginata, alteris duabus pone medium multo longioribus, linearibus et bene separatis, externa duplo interna longiore et hanc antice superante, haud nitidis, antice et postice nigro-marginatis. Pedes unicolores; femora intermedia et postica spinis duabus brevibus nigris, interna majori.

Long. 1 un. 2 lin. $\delta$.

Hab.-Santa Fé, Minas Geraes. A Dom. Rogers capta. 
colour of the derm is tawny-rufous, and this is covered by a fine and close tawny pubescence, which is of a silky golden-yellow hue in fresh specimens. On the head and thorax this pubescence is tomentose, but on the elytra and the under-surface of the body, it consists of very fine short hairs. There are no long erect bristles, as in many other species, but the antennæ have the usual fringe underneath the basal joints. The narrow black lateral margin to the elytra occupies the groove formed by the upturned lateral edge. It exists also in $E$. octoguttata, but is here rendered more conspicuous by the light tawny-reddish hue of the surface.

Hab.-Pebas, Upper Amazons; also Venezuela, where it was taken by Mr. Goering, in the neighbourhood of Lake Valencia.

\section{Genus Eburodacrys.}

\section{Thomson, Classif. des Ceramb. p. 288; Lacord. Gen. viii. 296.}

Distinguished from Eburia by the more abruptly clavate form of the anterior femora, and especially by the grooved third and fourth joints of the antennæ. The middle and hind femora are more elongate and slender, and always terminated by a single elongate spine.*

* Lacordaire gives the glabrous surface of the body as one of the distinguishing characters of Eburodacrys, but E. sexmaculata, E. citreoguttata (Thoms.), E. longipilis and others here described, are clothed above with very long hairs. The following fine large species also is thickly clothed with long erect hairs.

\section{Eburodacrys cacica (Dej. Cat.), n. sp.}

Hujus generis species maxima, fulvo-rufa, pilis elongatis fulvis erectis vestita. Caput grosse punctatum. Antennæ articulo basali crasso ( $q$ ), grosse punctato, antice concavo; articulis 3io et 4to sulcis haud profundis. Thorax subquadratus, grosse densissime rugoso-punctatus, medio linea glabra, lateribus spina valida nigra antice linea nigra connexa, dorso tuberculis validis conicis nigris duobus instructus. Elytra dense punctata, postice læviora, nitida, apice oblique truncata et bispinosa, utrinque maculis eburneis elongato-ovalibus geminatis duabus, una basali macula externa dimidio minore, altera pone medium macula externa duplo majore, antice et postice internam superante, omnibus maculis nigris, lanceolato-terminatis. Pedes minus elongati, femora apice nigra, intermedia et postica longe unispinosa.

Long. 1 un. 2 lin..+

Hab.-Cayenne. 


\section{Eburodacrys megaspilota.}

White, Cat. Longic. Brit. Mus. p. 95, pl. iii. f. 4 .

Elongata, testaceo-rufa; thorace angustiori, supra leviter transversim rugoso, medio spatio elevato lævi, spinis dorsalibus duabus validis, lateralibus duabus magnis, nigris ; elytris apice transversim truncatis, spina suturali minima, marginali longissima, supra grosse punctatis, parce setosis, apice sublævibus, macula magna rotundata eburnea basali, alteris duabus magis elongatis pone medium antice contiguis postice divergentibus, interiori oblonga, exteriori duplo longiori leviter curvata ; pedibus valde elongatis, gracilibus, femoribus apice nigris, intermediis et posticis unispinosis.

Long. 9 lin. $\delta$.

Mr. White suggested that this species might form a new subgenus near Holacanthus (Nyssicus, Pasc., Lacord.); it is, however, a true Eburodacrys, and, perhaps, the most typical of the genus.

Hab.-Ega.

\section{Eburodacrys longipilis, n. sp.}

Elongata, subcylindrica, testaceo-rufa, pilis longissimis sparsis passim hirsuta ; thorace grosse transversim punctato-rugoso, spina laterali acuta nigra, antice cum tuberculo anteriore linea nigra indistincta connexa, dorso tuberculis nigris duobus, interdum in linea nigra postice continuatis ; elytris dense punctatis, postice sublævibus, macula elongato-ovata eburnea basali, alteris duabus pone medium magis elongatis, exteriori paulo longiori, antice conjunctis postice divergentibus, apice transverse truncatis et extus unispinosis; pedibus minus elongatis, femoribus nigris unispinosis.

Long. 7-8 lin. $\delta$ \% .

Allied to E. puella, Newman, but apparently distinct. In two of my specimens (from Cayenne) there are two indistinct black lines on the thorax, posterior to the black dorsal tubercles, but in the third (from Ega) these are absent. The two median ivory spots of the elytra commence exactly together at their anterior extremity; they have there a triangular black spot common to both; 
at their hind extremity, each has a longer triangular black spot. There is a short fulvous pubescence on the elytra, besides the longer hairs.

Hab.-Ega; also found at Cayenne.

\section{Eburodacrys hirsutula, n. sp.}

E. longipili valde affinis, differt maculis eburneis elytrorum posticis paulo magis separatis, interiori antice exteriorem superanti; testaceo-rufa, pilis longissimis sparsis passim hirsuta; thorace grosse transversim punctato-rugoso, spina laterali acuta nigra, dorso tuberculis duobus nigris; elytris dense punctatis, postice sublævibus, macula elongato-ovata eburnea basali, alteris duabus pone medium haud longioribus, exteriore paulo magis retrorsa; pedibus elongatis, femoribus apice haud nigris, intermediis et posticis unispinosis,

Long. $6 \frac{1}{2}$ lin. $\delta$.

The elytra, as in $E$. longipilis, have a short fulvous pubescence, besides the longer hairs; the apices are unispinose, with a black streak proceeding from the spine. The thorax has no black lateral streak, and the legs are entirely unicolorous. The posterior spots of the elytra are not longer than the basal one, but are a little more pointed.

Hab.-Santarem, Amazons.

\section{Eburodacrys rufispinis, n. sp.}

Elongata, sublinearis, fulvo-testacea; thorace subcylindrico, spinis lateralibus parvis vix conspicuis fulvis, tuberculo laterali antico nigro, supra transversim rugoso et tuberculis obtusis rotundatis nigris, medio plaga elongata elevata; elytris glabris, grosse punctatis, apice sublævibus, macula eburnea oblonga basali, alteris duabus contiguis pone medium, exteriori paulo longiori; spinis apicalibus, geniculis spinisque femorum nigris.

Long. 7-8 lin. of $q$.

Also closely allied to $E$. longipilis; differs in its glabrous surface, having but very few long hairs, except on the antennæ and legs, and wanting entirely the short pubescence. The lateral spines of the thorax are very small and acute, which gives the thorax a more cylindrical appearance. The ivory spots are margined before 
and behind, as usual, with black spots; the basal spot is oval; the posterior ones are close together, very little more elongate than the basal one, and the exterior is distinctly posterior to its companion in front, but is much longer and broader behind.*

$$
\text { Hab.-Ega. }
$$

\section{Eburodacrys sexmaculata.}

Cerambix 6-maculatus, Oliv. Entom. No. 67, p. 47, pl. xv. f. 108; Stenocorus 6-maculatus, Fabr. Ent. Syst. I. ii. 295.

Elongata, testaceo-fulva, pilis longis sparsis hirsuta et breviter pubescens; thorace spina laterali brevissima nigra cum linea nigra connexa, supra grosse punctatorugoso, bituberculato lineisque duabus abbreviatis dorsalibus nigris; elytris dense punctatis, apice sublævibus, utrinque maculis ovatis tribus bene separatis flavo-eburneis; spinis et geniculis nigris.

Long. $7 \frac{1}{2}-9$ lin. $\delta$ o 9 .

Var. 1. Thorace supra tuberculis solum nigris et lateribus spina maculaque nigris haud nigro-lineatis. Hab.-Pará, Amazon. sup.

Var. 2. Elytrorum maculis duabus posticis eburneis magis minusve postice distantibus, interdum pro parte parallelis. Hab.-Amazon. sup., Venezuela.

Var. 3. Geniculis concoloribus, spinis solum nigris. Hab.-Pará.

Var. 4. Spina laterali thoracis obsoleta. Hab.-Ega.

In a large series of this species before me, there are no two specimens exactly alike. The posterior spots

* A species closely allied to E. rufispinis is-

\section{Eburodacrys raripila, n. sp.}

Ab E. rufispini differt corpore pilis raris hirsuto, maculis duabus eburneis posticis late separatis divergentibus, exteriore magis retrorsa. Testaceorufa, vertice macula nigra; thorace spina laterali parva et tuberculo antico rufis, supra valde transversim rugoso, tuberculis duobus obtusis nigris, medio spatio elevato ; elytris fortiter confluenter punctatis, apice lævibus, macula oblonga eburnea basali, alteris duabus pone medium bene separatis, maculis elongatis nigro-terminatis, exteriore haud longiore, prope medium interioris incipiente; spinis geniculisque nigris.

Long. $6 \frac{1}{2}$ lin. $\delta$.

Hab.-Cayenne. 
especially vary much in relative position. In specimens which agree with the type of Olivier, the third spot is far from reaching the level of the apex of the second. I find this character only in specimens from Cayenne, Pará, and South Brazil; but the South Brazilian differ in other points, and perhaps merit specific separation. In other examples, the third spot at its base is nearly or quite level with the apex of the second. This form occurs with the type at Pará, and is the prevalent form on the Upper Amazons. Lastly, examples occur in which the third spot is so much advanced, that it is parallel with the second for about one-fourth their respective lengths. Such examples are furnished by Venezuela and the Upper Amazons. These approach in the position of the spots $E$. longipilis and the allied species, but $E$. sexmaculata is a larger and more robust insect; and besides, I have not yet seen specimens in which the posterior spots are quite contiguous.*

\section{Sub-fam. SPHÆRIIN}

Genus Nyssicus.

Pascoe, Trans. Ent. Soc., 2 ser., v. 17; Lacord. Gen. viii. 314 .

\section{Nyssicus quadrinus, n. sp.}

Minus elongatus, depressus, testaceo-fulvus, nudus; capite crebre punctato; thorace lateribus breviter obtuse tuberculato, supra inæquali plagiatim punctulato, linea mediana elevata, macula nigra apud marginem anticum, altera ad marginem posticum; elytris apice unispinosis, angulo suturali nullo, supra sparsim setosis punctulatis

* The following may be added to the now numerous list of species of this genus :-

Eburodacrys arcifera, n. sp.

Elongata, gracilis, depressa, fulvo-testacea ; thorace elongato, transversim punctato-rugoso, linea dorsali lævi, spina minuta laterali; elytris apice truncatis, spina laterali elongata obliqua nigra, suturali minuta fulva, supra punctatis nitidis, sparsim longe pilosis, linea eburnea recta basali, alteris duabus longioribus pone medium, interiori recta, exteriori duplo longiori, arcuata ; femoribus elongatis gradatim incrassatis, intermediis et posticis spina longa nigra armatis.

Long. 8 lin. $\delta$.

Hab.-Santa Fé, Minas Geraes. A Dom. Rogers capta. 
nitidis, maculis eburneis utrinque duabus ovatis, una (antice nigro-marginata) paulo ante medium, altera (paulo exteriori) pone medium, macula humerali nigra ; geniculis fuscis.

Long. 7 lin. 8 .

Hab.-Tapajos.

\section{Genus Spharion.}

Serville, Ann. Soc. Ent. Fr. 1834, p. 68 ; Lacord. Gen. viii. 315 .

1. Sphorion callidioides, $\mathrm{n}$. sp.

Depressum, ferrugineum, capite antice, antennis pedibusque nigris ; elytris nigris vel ferrugineis, pube subtile cinerea indutis et sparsim nigro-setosis, punctulatis, apice unispinosis, inter spinam et suturam breviter sinuatis, angulo suturale acuto; capite dense punctato; thorace transverso, lateribus tuberculo lato conico alteroque antico, supra quinque-tuberculato, sparsim punctato; femoribus clavatis ; antennis articulis 3-5 unispinosis.

Long. $6 \frac{1}{2}-7 \frac{1}{2}$ lin. $\delta$.

Undoubtedly congeneric with the typical form $S$. cyanipenne, Serv. The species somewhat resembles in general form and range of colours Callidium (Phymatodes) variabile, but is broader. It seems to be closely allied to Sph. rusticum (Burmeister), from Uruguay; but I cannot feel sure of the identity of the two from the description.

Hab.-Santarem ; Tapajos.

Found flying at night in and around houses.

\section{Sphcerion ducale, n. sp.}

Magnum, subdepressum, rufo-castaneum, antennis (articulo basali excepto), tibiis, maculis basalibus et marginalibus lineaque suturali nigris; capite inter antennas subplano ; thorace magno, lateribus medio tumido rotundato, supra tuberculis duobus obtusis alterisque linearibus lævibus, interstitiis rugoso-punctatis, lateribus punctatis opacis; scutello fulvo-sericeo; elytris apice unispinosis, angulo suturale obtuso, supra punctatis, pube subtilissima cinerea indutis, macula basali, marginibus (apicalibus exceptis), sutura usque pone medium et ibidem fascia 
interrupta, nigris; femoribus robustis, clavatis ; corpore subtus pube sericea cinereo-fulva dense vestito, prothorace opaco lanuginoso punctato.

Long. 1 un. 1 lin. $\delta$.

Allied to Sph. procerum, Erichs. (in Schomb. Reis. Brit. Guiana), differing chiefly in colour, and in the markings of the elytra.

Hab.-Tapajos. I found it in repose on a leaf in the forests.

\section{Genus Peribeum.}

Thomson, Syst. Ceramb. p. 245 ; Lacord. Gen. viii. 318.

According to Lacordaire, this genus is distinguished among the Sphoriince, by the pedunculate femora, i.e., slender at the base and clavate beyond the middle, by their unarmed apices, and by the integument being glabrous or not clothed with fine pubescence as in Sphcerion proper. One of the species here described invalidates this definition, as it possesses the abruptly clavate form of the femora characteristic of Periboeum, and their bispinose apices, which is distinctive of the genus Nephalius.

\section{Periboum pubescens.}

Cerambix pubescens, Olivier, Ent. No. 67, p. 33, pl. xviii. f. 135 .

Minus elongatum, postice attenuatum, rufo-castaneum, nitidum, longe et sparsim griseo-hirsutum; capite et dimidio apicale elytrorum nigris, interdum capite solum nigro; thorace tuberculo valido laterali aliisque quatuor et carina mediana dorsalibus ; elytris sparsim punctulatis, punctis piliferis asperatis, apice truncatis et unispinosis.

Long. 4-8 $\frac{1}{2}$ lin. $\delta$ 우 .

Common throughout the Amazon region. Varies from clear reddish-chesnut, with the head alone black, to dark chesnut, with the head, thorax, apical half of the elytra, and abdomen, black. The head, basal joint of the antennæ, and underside of the prothorax, are clothed with grayish tomentum. 


\section{Periboum ebeninum.}

$P$. pubescenti valde affinis; differt corpore toto aterrimo, politissimo, capite, articulo basali antennarum, et prothorace subtus opacis griseo-tomentosis, sternis lateraliter sericeis.

Long. 9 lin. $\delta$.

Hab.-Pebas, Upper Amazons.

\section{Periboum lissonotum, n. sp.}

Angustatum, castaneo-rubrum, nitidum, antennis pedibusque nigris; thorace elongato subcylindrico, lateribus rotundatis, supra lævi; elytris apice sinuato-truncatis, bispinosis, spina suturali brevi ; pedibus brevibus, femoribus prope apicem clavatis, intermediis et posticis bispinosis.

Long. $5 \frac{1}{2}$ lin. $\delta$.

A species belonging to Nephalius (Lacord.), by the form of the thorax and the bispinose femora, but to Periboum by its abruptly clavate femora, and especially by its evidently close relationship to $P$. pubescens. The colour is reddish-chesnut, with the antennæ and legs pitchy-black, the derm shining, but trunk and limbs clothed equally with very long and straight hairs. The head is strongly punctured, and naked; the thorax is elongate, rounded, and quite unarmed on the sides, polished on the disc, and with a very strong bi-arcuate transverse furrow near the hind margin; the sides are strongly punctured in patches, and the underside is evenly punctured. Scutellum naked. The elytra are not much wider than the thorax, and relatively not very elongate; the surface is coarsely punctured, except near the apex; the extreme tip, and the spines, are black.*

$$
\text { Hab.-River Tapajos. }
$$

* Other species exist which supply still further connecting links between Peribœum and Nephalius, as defined by Lacordaire ; among them is-

$$
\text { Nephatius fragilis, n. sp. }
$$

Elongatus, subdepressus, nitidus, pilis sparsis erectis hirsutus, rufotestaceus, antennis, elytris, femoribus basi, tibiis et tarsis pallidioribus. Caput plagiatim punctatum. Thorax elongatus, lateribus medio paulo rotundato-dilatatis, supra antice et postice constrictus et transversim sulcatulus, supra diseo omnino lavi. Elytra postice attenuata, apice truncata et bispinosa, spina suturali brevi, ambabus nigris; supra lævia, versus basin solum sparse punctata. Femora distincte clavata, apice bispinosa, spina interiori longiori.

Long. $5 \frac{1}{2}$ lin.

Hab.-Rio Janeiro (E coll. Dom. Rev. Hamlet Clark). 


\section{Genus Apospherion, nov. gen.}

Thorax elongatus, angustatus, cylindricus, omnino lævis. Antennæ articulis 3-11 sulcatis, carinatis, et (11mo excepto) apice spinosis. Pedes breves; femora abrupte clavata, inermia.

Differs from all the other genera of Sphceriince in the form of the thorax, which is greatly elongate, and almost perfectly cylindrical, without a trace of lateral spine or dorsal inæqualities or punctures; it has only a single transverse curved impression near the base. The elytra are nearly twice the width of the thorax at the base, and taper regularly thence to the apex, where they are truncate and bispinose, the sutural spine much the smaller ; the surface is nearly impunctate, except at the base, where, for a small space, they are very strongly punctured, and there are only a few long hairs. The chief peculiarity of the genus, however, is in the antennæ, without which I should have hesitated to separate it from Periboeum. This consists in the grooves and carinæ, which in the allied genera are confined to the third, fifth, or sixth joints, but are here extended to the apex ; all these joints being spinose at the tips, except, of course, the eleventh. The legs are short, and the femora abruptly clavate, and quite unarmed at the tips. The palpi are extremely short, with the terminal joints triangular. The intermediate sockets are closed; the anterior haunches are globular, with the narrow prosternum sunk between them.

Notwithstanding the cylindrical form of the thorax, the genus has not at all the facies of Ibidion, a circumstance which arises from the thorax not having the arched appearance characteristic of the Ibidion group.

\section{Aposphcerion longicolle, $\mathrm{n}$. sp.}

Angustatum, castaneum, politum ; capite antice sparse punctato ; thorace cylindrico, lævi, prope marginem posticum arcuatim sulcato; elytris postice attenuatis, apice bispinosis, supra lævibus, prope basin aspere punctatis, postice prope suturam punctis nonnullis setiferis.

Long. $4 \frac{1}{2}-7 \frac{1}{2}$ lin. of $q$.

Hab.-Obydos, Lower Amazons; on branches of dead trees. 


\section{Genus Pantonyssus, nov. gen.}

Allied to Nephalius, as defined by Lacordaire, but differing essentially in the middle and hind femora being linear, or nearly linear, with a single long spine externally at their apices, as in Eburodacrys. In Nephalius (with which I think Castiale, Pascoe, ought to be incorporated, as it offers precisely the same generic characters), the posterior femora are more or less fusiform, or gradually enlarged from the base, and the spines at their apices are always two in number; moreover, when there is an inequality in the length of these femoral spines, it is the interior one which is the longer ; quite the opposite of what is seen in Pantonyssus. The head, antennæ, and sterna offer no differences. The antenniferous tubercles are united, and form an even elevation across the forehead; the third to sixth or seventh antennal joints are spined, and the third and fourth are grooved and carinate; the basal joint is concave in front.

\section{Pantonyssus Erichsoni.}

Spharion Erichsonii, White, Cat. Longic. Brit. Mus. p. 108.

Elongatus, angustatus, minus convexus, pilis elongatis erectis griseis hirsutus; capite antice, antennis, pedibus, apiceque elytrorum nigris; thorace elongato, inerme, supra obsolete quinque-tuberculato et transversim rugoso; elytris apice truncatis et bispinosis, spina suturali brevissima, supra irregulariter punctatis, apice sublævibus, punctis nonnullis asperatis; femoribus valde elongatis, linearibus.

Long. 7-7 $\frac{1}{2}$ lin. $\delta$.

Hab.-Pará.*

* A second species of this genus is the following:-

Pantonyssus nigriceps, n. sp.

Elongatus, minus convexus, sparsim flavo-hirsutus, flavo-testaceus, capite articuloque basale antennarum nigris. Caput plagiatim punctatum. Thorax oblongus, lateribus rotundatis, supra obsolete 5 -tuberculatus, interstitiis et lateribus sparsim grosse punctatis. Elytra postice attenuata, apice truncata et bispinosa, spina suturali parva, marginali nigra, supra sparsim haud profunde punctata, nitida. Femora linearia, leviter fusiformia, spinis apicalibus fuscis.

Long. $6 \frac{1}{2}$ lin. $\delta$.

Hab.-Rio Janeiro (a Dom. Rev. Hamlet Clark lectus, prope Tejuco). 


\section{Genus Atharsus.}

Bates, Entom. Monthly Mag. iv. 25 (1867); Lacord. Gen. viii. 323.

Lacordaire suggests that Burmeister's Sphcerion rusticum may be closely allied to Atharsus; but I have no doubt, from Burmeister's description, that his insect is a true Sphorion, and near my Sph. callidioides. Atharsus differs in having a slight trace of the antennal grooves only on the third joint, and in the absence of spines at the apex of the elytra. The third to fifth joints of the antennæ have a short spine at the apex. The great relative length of the maxillary palpi, and the depressed form of body, with its clothing of excessively fine ashy pile, show a close relationship to Sphoerion proper. The femora are very gradually clavate, and unarmed at the tips. There is only a feeble trace of carina on the hind tibiæ.

\section{Atharsus nigricauda, Bates, loc. cit.}

Brevis, depressus, rufo-testaceus, vix nitidus, pube subtili cinerea indutus, haud pilosus, elytris, capite antice, antennis, quinta parte apicali elytrorum, et pedibus nigris ; antennis sparsim subtus ciliatis.

Long. 5 lin. $\delta$.

Hab.-Tapajos.

Genus Terpnissa.

Bates, Entom. Monthly Mag. iv. 25 (1867); Lacord. Gen. viii. 324 .

Elongata, sublinearis, opaca, sparsim hirsuta. Caput antice brevissimum, palpis maxillaribus valde elongatis: antennis setaceis, corpore dimidio longioribus, articulis 3-5 unicarinatis, apice unispinosis. Thorax rotundatoovatus, lateribus medio angulatis, supra convexus, paulo inæqualis. Elytra linearia, ante apicem rotundata, deinde breviter truncata, angulo externo spinoso, suturali haud producto. Prosternum inter coxas angustissimum, coxis orbiculatis; mesosternum latum, acetabula clausa. Pedes elongati, femoribus clavatis, pedunculatis, apice inermibus; tibiis compressis, vix perspicue intus sulcatis ; tarsis brevissimis.

TRANS. ENT. SOC. 1870.-PART III. (AUGUST.) 
The genus undoubtedly belongs to the Sphceriince by the majority of its characters, although the facies is entirely different, owing to the sub-orbicular form of the thorax; the tibiæ are not perceptibly sulcate.

\section{Terpnissa listropterina, Bates, l. c.}

Nigricans, pube tenui cinerea induta, et sparsim nigrosetosa; antennis (articulis quatuor basalibus exceptis) flavis ; capite postice thoraceque rufis, rufo-sericeis ; elytris punctulatis, cinereis, basi, lateribus, vittaque mediana abbreviata, nigris.

Long. $5 \frac{1}{2}$ lin. $\delta$.

Hab.-Tapajos.

Resembles certain species of Listroptera in the ashy clothing of the underside, and the markings of the elytra.

\section{Genus Mallocera.}

Serville, Ann. Soc. Ent. Fr. 1833, p. 567 ; Lacord. Gen. viii. 320 .

\section{Mallocera amazonica, n. sp.}

Elongata, nigra, pube variante argenteo-sericea vestita, elytris passim breviter nigro-setosis, capite subtus et pectore longe hirsutis ; antennis subtus ciliatis, articulis 3-6 carinatis et apice unispinosis ; thorace elongato, lateribus medio tuberculo magno, dorso quadri-tuberculato et medio linea impressa ; elytris apice oblique truncatis et unispinosis, argenteo-sericeis, fasciis duabus latis indistinctis nigris, una prope basin transversali dentata, altera ad medium obliqua, apice certo situ nigricante; pedibus valde elongatis, robustis, femoribus medio paulo incrassatis, apice inermibus.

Long. 10 lin. $\delta$.

Much resembling $M$. glauca, Serv., the type of the genus, but differing in the setose elytra, and in the apex of the same having one spine only instead of two. The setæ of the elytra are rather short, black, and rigid, and cover the whole surface with the greatest regularity; the punctures from which they spring are not visible, owing 
to the dense changeable silky pile with which the surface is clothed. This silvery or pale golden pile seems spread over the whole elytra, but black markings always appear, which vary according to the position in which the insect is held; their most constant form, however, appears to be that of an undulating belt near the base, and an oblique belt (from the suture rearwards towards the margin) about the middle. The under-surface of the body is clothed with a similar silky pile, but the throat and the centre of the breast have a very dense beard of long pale soft hairs.

Hab.-Ega and Pebas, Upper Amazons; two males.

\section{Genus Appula.}

Thomson, Syst. Ceramb. p. 245; Lacord. Gen. viii. 322.

\section{Appula nigripes, $\mathrm{n}$. sp.}

A. laterali et undulante (White) differt corpore magis cylindrico elytrisque multo brevioribus; pube nigra argenteo-sericea vestita; thorace cylindrico, antice et postice constricto, medio paulo rotundato, supra æquali, linea dorsali abbreviata glabra; elytris ante apicem rotundatis, recte truncatis, angulo exteriori spinoso, suturali producto, supra sparsim hirsutis et punctatis, medio maculis et fasciis nigris, apice certo situ nigricantibus; pedibus validis, setosis, femoribus paullo incrassatis.

Long. 8 lin.

Resembles much Mallocera glauca and amazonica, in the silky changeable pile with which it is clothed, and the vague black markings of the elytra, but differs in the long single exterior spine of the middle and hind femora, which in this group is a tolerably stable generic character. The thorax, too, has no trace of tubercies, either on the sides or disc, and in this respect the insect recedes more from the Mallocera type than do Appula lateralis and undulans. The elytra, instead of the short dense black bristles, have a more scanty clothing of fine long erect hairs.

Hab.-Tapajos. 


\section{Sub-fam. Piezocerinæ.}

Genus Haruspex.

Thomson, Syst. Ceramb. p. 221; Lacord. Gen. viii. 326.

\section{Haruspex lineolatus, n. sp.}

H. brevipedi (White) $*$ simillimus, sed antemnis elongatis filiformibus, haud serratis. Rufescens, subtus nitidus, supra opacus, breviter sparsim setosus ; capite dense punctato; thorace subcylindrico, angustato, lateribus vix rotundato, postice constricto, supra æquali, eleganter reticulato-punctato; elytris truncatis et bispinosis, supra dense subrugose punctatis, medio vitta irregulari nigricante, lineolas duas flavas includente, una prope basin longiore, altera pone medium multo breviore, intus paulo dilatata, lineolis supra lineam discoidalem elevatam sitis; pedibus brevibus, femoribus clavatis.

Long. $5 \frac{1}{2}$ lin. $\delta$.

Although the antennæ have elongate linear joints, unlike the majority of the Piezocerince, which have the antennæ flattened and serrate, they agree in being grooved and carinate to near the apex, and they are finely and sparsely hirsute above and beneath. The surface of the thorax is closely covered with shallow pits, and has a honeycombed appearance, without any impunctate interval; this character, together with the narrow form of the thorax, only half the width of the elytra, readily distinguishes the species from the common Brazilian H. brevipes.

Hab.-Santarem, Amazons.

\section{Haruspex modestus.}

Phyton modestum, White, Cat. Longic. Brit. Mus. p. 239.

Angustatus, cylindricus, testaceo-rufus, opacus, prothorace pectoreque subtus nigris; antennis corpore multo longioribus, filiformibus, vix pilosis; thorace oblongoovato, postice valde constricto, supra quadri-tuberculato, subtiliter rugoso et punctato, postice utrinque linea obliqua nigra; elytris apice sinuato-truncatis et breviter bidentatis, supra grossissime punctatis, linea longitudinali elevata, pone medium utrinque fascia obliqua et post hanc macula communi triangulari fuscis.

* Ozodes breripes, White, Cat. Longic. Brit. Mus. p. 218. 


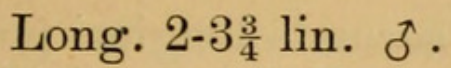

Belongs undoubtedly to the genus Haruspex, from the grooved and carinate antennal joints and tibiæ.

Hab.-Tapajos.

\section{Haruspex maculicornis, n. sp.}

Cylindricus, fulvo-testaceus; thorace rotundato, vittis discoidalibus duabus; elytris macula triangulari humerali plagaque magna communi postica violaceo-fuscis, apice breviter emarginatis.

Long. 4 lin. $\delta$.

Of cylindrical form, the head and thorax narrower than the elytra. The head is opaque, yellowish ; the antennæ, a little longer than the body, are filiform, not at all serrate, pubescent, grooved and carinate to the tenth joint, the four basal joints chesnut-red, the rest testaceous yellow, with the tips of the joints brown. The thorax forms a somewhat regular oval, and is not much constricted behind, with the groove not strictly marked; the surface is densely and confluently punctate, testaceous yellow or tawny, with a broad vitta on each side of the disc purplish-brown, not touching either front or hind margin. The elytra are rounded, and much narrowed close to the tips, the latter simply notched; the surface is covered with large deep circular punctures ; the longitudinal elevated line of the disc becomes wavy near the middle, and then disappears; the colour is testaceous, with a large triangular humeral spot, and a spot occupying the whole apical half, violet-brown, this spot being advanced and rounded on the suture. Beneath, entirely testaceous-yellow, shining; the legs the same, with the tips of the thighs and base of the tibiæ brown.

$$
\text { Hab.-Pará. }
$$

\section{Haruspex ornatus, n. sp.}

Brevis, cylindricus, fulvo-testaceus ; thorace rotundato, crebre rugoso-punctato, postice profunde flexuoso sulcato, supra utrinque vitta lata abbreviata fusco-violacea; elytris apice oblique truncatis, extus breviter late dentatis, supra crebre grosse punctatis, linea elevata mediana, maculis vel fasciis obliquis abbreviatis fusco-violaceis 
utrinque tribus, una subhumerali, secunda longiori pone medium, tertiaque transversa subapicali; antennis filiformibus, breviter pilosis.

Long. $4 \frac{1}{4}$ lin. $\delta$.

Rather shorter in form and more regularly cylindrical than the other species, wholly fulvo-testaceous in body and limbs, except two purplish-brown vittæ on the thorax, and three belts or spots of the same colour on each elytron. The punctuation of the elytra is so large and dense, even to the apex, that the whole surface seems honeycombed.

Hab.-Santarem, Amazons.

\section{Haruspex pusillus, n. sp.}

Parvus, linearis, sparse setosus, ferrugineo-testaceus, elytris vitta suturali indistincta et pone medium interrupta flavescenti; capite reticulato-punctato, antennis subfiliformibus, serratis, corpore $\left(\delta^{\star}\right)$ paulo longioribus, (ㅇ ) paulo brevioribus, articulo basali scabroso, reliquis usque ad apicem sulcato-carinatis; thorace subcupuliformi, basi fortissime constricto, supra parum profunde reticulato-scabroso, opaco; elytris minus convexis, apice breviter sinuato-truncatis, extus longe dentatis, angulo suturali breviter spinoso, supra grosse punctatis opacis, suturam et apicem versus minus dense, subnitidis: pedibus validis, femoribus modice clavatis, tibiis omnibus apice extus spinoso-productis.

Long. $2 \frac{1}{4}-2 \frac{1}{2}$ lin. $\delta$ o .

A curious little species, approaching Piezocera in having the apices of the tibiæ externally produced and acute, but without the sharp exterior edge of these members, which is a distinguishing character of Piezocera. The thorax does not differ essentially in form from that of $H$. brevipes, but it has a peculiar appearance, owing to the sides not being rounded, and the usual constriction near the hind margin being unusually strong, with a correspondingly deep sulcus ; this is, however, much more marked in the $\delta$ than in the $q$.

Hab.-Santarem, Amazons.*

* There may be added to the above :-

Haruspex simplicior, n. sp.

Elongatus, longe pilosus, testaceo-ferrnginens, elytris et corpore subtus nitidis. Caput, articulus basalis antennarum, et thorax, reticulato-scabrosi, 
Genus Pyrgotes.

\section{Bates, Entom. Monthly Mag. iv. 27 (1867).}

Corpus elongatum, angustum, capite thoraceque valde angustatis, lævibus, nitidis. Antennæ articulis 3-11 valde explanatis, a basi abrupte dilatatis, apice utroque angulo æque producto. Thorax angustus, cylindricus, postice constrictus, post medium tuberculo laterali. Pedes validi, tibiæ mox pone basin compresso-dilatatæ. Reliqua ut in Piezocera (Serv., Lacord.).

Lacordaire, judging from the description alone, concluded that the present genus was identical with Piezocera, and even that the species might be the same as Piezocera bivittata, Serv. The description of the antennæ of Pyrgotes ought to have prevented him from falling into this error. In fact, the form of the antennal joints is entirely different; both the apical angles of the third to the tenth being equally produced and pointed. The genus, in fact, is much more distinct from Piezocera than are Haruspex and Gorybia. Between Pyrgotes aeneus and Piezocera bivittata there is no resemblance of form, and but little of sculpture or colour.

\section{Pyrgotes ceneus, Bates, $l$. c.}

Lævis, nitidus, sparsim breviter fulvo-setosus, castaneus, elytris (marginibus angustis exceptis) læte viridiæneis; thorace nitido, impunctato, nigro-setoso, medio nigricanti sericeo; elytris sparsim punctulatis, apice oblique truncatis, angulis rotundatis.

Long. $3 \frac{1}{4}$ lin.

Hab.-Ega.

opaci. Antennæ articulis a 3io usque ad 10mum serratis, deplanatis, et cum 11mo sulcato-carinatis, sparse ciliatis. Thorax oblongo-ovatus, postice constrictus. Elytra sinuato-truncata, angulo externo longe dentato, suturali acuto, supra grosse sed non dense punctata, nitida. Femora distincte clavata, nitida: tibiæ apice haud productæ nee compressæ, carinatx.

Hab.-Rio Janeiro (E coll. Dom. Rev. H. Clark). 


\section{Genus Hemisisa.}

Pascoe, Trans. Ent. Soc., 2 ser., iv. 238; Lacord. Gen. viii. 327.

\section{Hemilissa sulcicollis, n. sp.}

Elongata, subcylindrica, nigro-castanea, abdomine rufescenti, setis longis hirsuta, nitida ; capite grosse sparsim punctato, nitido, tuberibus antenniferis intus vix perspicue productis ; antennis corpore longioribus, articulis haud dilatatis sed distincte serratis, basali scabroso, a 3io ad $11 \mathrm{mum}$ carinatis; thorace oblongo, grossissime scabroso, sulco medio lato profundo, fundo politissimo; elytris truncatis, extus longe spinosis, angulo suturali recto, supra basin versus asperato-punctatis, punctis seriatis, parte apicali sublævi polita; femoribus abrupte clavatis.

Long. $4 \frac{1}{2}$ lin. 8 .

Resembles in form and colouring Sphcerion (Peribœum) pubescens; but clearly allied to Hemilissa gummosa, the type of the present genus.

Hab.-Ega.

\section{Hemilissa cornuta, n. sp.}

Elongata, breviter pilosa, fusco-violacea, supra opaca, infra nitida, abdomine rufescenti; capite opaco, grosse punctato, tuberibus antenniferis intus valde productis cornutis ; antennis opacis, compressis, serratis, articulo basali scabroso ; thorace oblongo, postice constricto, sine sulco, medio dilatato rotundato, opaco, reticulato-scabroso et asperato, medio supra nigricanti ; elytris apice truncatis, extus unispinosis, supra lineatim punctatis, postice punctis minoribus et magis confusis; pedibus validis, femoribus clavatis scabrosis.

Long. 7 lin. (ㅇ ?).

A handsome and remarkable species; differing from H. gummosa in the total absence of gloss from the elytra, but presenting in a still more marked degree the generic character of pointed inner angles of the antenniferous tubers.

Hab.-River Tapajos.

One example, found on a leaf in the forests of the Cupari. 
Sub-fam. IBidiIne.

Genus Hexoplon.

Thomson, Syst. Ceramb. p. 219.

Antennæ with all the joints linear; femora elongate, linear, or very little incrassate, the intermediate with a long spine on the inner side of the apex, the posterior with a long spine on the outer side.

Lacordaire unites Hexoplon with Gnomidolon.

\section{Hexoplon flaveolum, n. sp.}

Angustatum, sublineare, flavo-testaceum, capite plus minusve infuscato vel nigro; elytris fasciis duabus testaceo-albis, prima suturam haud attingente ante medium, secunda integra pone medium, apicem versus interdum infuscatis, apice truncatis et extus unispinosis; toto insecto longe sparsim setoso et nitido; thorace impunctato ; elytris seriatim punctatis, apicem versus lævibus, supra medio vix depressis.

Long. $4 \frac{1}{4}-5$ lin.

Hab.-Tapajos and Ega.

\section{Hexoplon quincunx.}

Thomson, Physis, i. 162.

Lineare, elytris postice ut in genere Ctenostoma (Cicindelidarum) valde convexis, longe sparsim griseo-setosum; capite antice flavo, postice sericeo-nigro ; thorace testaceofulvo, dorso plaga magna postice trifida sericeo-nigra; elytris dimidio basali flavido, figuram magnam $\mathrm{X}$-formem includente, post hanc partem brunneo-rufescentibus, deinde juxta apicem albis, parte antica seriatim punctata, postica subtilissime rugulosa, opaca; pedibus flavo fuscoque variegatis.

Long. $4-5 \frac{1}{2}$ lin. $\delta$ \& .

Hab.-Ega ; found abundantly, concealed in folded leaves of trees in the day-time. 


\section{Genus Gnomidolon.}

Thomson, Syst. Ceramb. p. 219 ; Lacord. Gen. viii. 330.

Antennæ with all the joints linear; femora moderately elongate, and slightly thickened towards the middle, a long spine only at the apex of the hind femora, on the outer side.

\section{Gnomidolon Clymene.}

Thomson, Physis, i. 161.

Angustum, lineare, testaceo-rufum, longe pilosum, nitidum; capite sparse punctato; antennis unicoloribus ; thorace medio modice convexo, polito, interdum plaga dorsali nigra, vel toto nigro-castaneo polito ; elytris medio vel dimidio basali nigro-castaneo, macula triangulari marginali et paulo post hanc vitta obliqua albis, margine laterali (prope basin excepto) et apice testaceo-albis; elytris medio depressis.

Long. $3 \frac{1}{2}-4 \frac{1}{2}$ lin. of $q$.

Common. The space between tha white triangular spot and the oblique fascia of the elytra is not wider than the white belt; it is sometimes of a darker hue than the rest of the elytra, and looks then like a distinct dark fascia.

$$
H a b .-E g a .
$$

\section{Gnomidolon rubricolor, n. sp.}

G. Clymeni valde affinis, differt colore ferrugineo obscuriori et spatio inter fascias elytrorum multo latiori; ferrugineum, tibiis tarsisque obscurioribus, sparsim hirsutum, politum ; elytris apud medium fasciis duabus obliquis albo-testaceis, prima latiori suturam haud attingente, secunda angustiori integra, apice testaceo-albis.

Long. $4 \frac{1}{2}$ lin. $\delta$.

The two white marks of the elytra constitute two fasciæ, the first not being triangular. The distance between the two is twice the width of the posterior fascia.

Hab.-Tapajos. 


\section{Gnomidolon conjugatum.}

Ibidion conjugatum, White, Cat. Longic. Brit. Mus. p. 231.

Elongatum, lineare, sparse hirsutum, politum, nigrum, antennis femoribusque flavo-ferrugineis, tibiis articulisque primis antennarum nigro-fuscis; elytris fasciis duabus abbreviatis obliquis albis, margine connexis, apice albis.

Long. $2 \frac{3}{4}-3 \frac{3}{4}$ lin.

Among the glossy black species with white belts, the present is distinguishable by both belts halting far from the suture; the anterior is twice the width of the posterior, and is of the form of a triangular spot; the dark space between the two is also elongate-triangular.

Hab.-River Tapajos.

\section{Gnomidolon eganum, n. sp.}

G. conjugato affinissimum, differt fascia secunda elytrorum integra et prima haud triangulari.

Long. 4 lin.

Hab.-Ega.

5. Gnomidolon picipes, n. sp.

G. conjugato affine, sed minus, et pedibus piceo-rufis facile distinguendum; lineare, nigro-piceum, politum, sparse hirsutum ; antennis rufo-piceis, basi obscurioribus ; thorace lævi ; elytris striato-punctatis, apud medium fasciis duabus testaceo-albis, prima latiori suturam haud attingente, secunda angustiori integra, marginibus lateralibus apiceque testaceo-albis; pectore rufo ; pedibus rufo-piceis, femoribus apice longe unispinosis.

Long. 3 lin.

Hab.-Ega.

6. Gnomidolon humerale, $\mathrm{n} . \mathrm{sp}$.

Lineare, sparse hirsutum, politum, nigrum, antennis piceo-rufis, basi obscurioribus, femoribus rufo-ferrugineis ; 
thorace lævi; elytris apud medium fasciis duabus albotestaceis, prima latiori suturam haud attingente, maculaque elongata humerali rufo-ferruginea, apice albo-testaceis.

Long. 4 lin.

Closely allied to $G$. conjugatum, but having a rufous spot on the elytra, extending from the humeral angle to the first white belt; the second narrow white belt does not quite reach the suture; the femora and apical half of the tibiæ are clear rufous.

Hab.-Pará.

\section{Gnomidolon melanosomum, n. sp.}

G. picipedi affine, multo majus, thorace medio inæquali subtuberculato facile distinguendum; nigrum, ebeninum, politum, griseo-pilosum, antennis articulis 5 primis rufopiceis, reliquis pallidis, pedibus rufo-piceis ; elytris apud medium fasciis duabus obliquis albo-testaceis, prima vix latiori suturam haud attingente, secunda integra, apice albo-testaceis, hoc truncato et extus unispinoso ; corpore subtus lateraliter argenteo-sericeo.

Long. 6 lin. s .

Hab.-Ega.

\section{Gnomidolm subeburneum.}

Ibidion subeburneum, White, Cat. Longic. Brit. Mus. p. 234 .

Lineare, ferrugineo-fulvum, politum, griseo-setosum; capite grosse sparsim punctato; antennis unicoloribus; thorace lævi, postice plaga magna fusca polita, vel toto fusco; elytris medio valde depressis, seriatim punctatis, maculis duabus paulo ante medium, fascia obliqua integra pone medium, et apice late albo-testaceis; femoribus posticis spina valde elongata.

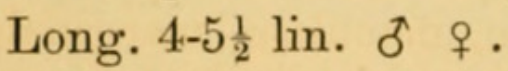

Hab.-Tapajos and Ega ; common in folded leaves of trees, in repose in the day-time.

The Ega specimens are bright rusty-tawny; those from the Tapajos are much darker, and are those in which the thorax is wholly blackish-brown above, the apices of the femora and the tibiæ are also of dark hue. The species 
also occurs at Cayenne, and is there still darker in its colours, the upper-side being black, with rufous lines on the elytra, and the legs partly reddish. In all, the markings are the same; the two whitish spots, which take the place of the anterior fascia, being elongate and nearly parallel, the outer one a little posterior, and near the lateral margin.

\section{Gnomidolon biarcuatum.}

Ibidion biarcuatum, White, Cat. Longic. Brit. Mus.

p. 228.

Elongatum, sparse pilosum, politum; capite nigro; thorace lævi, nigro antice et postice fulvo, vel fulvo macula postica antice trifida nigra; elytris depressis, melleo-flavis, apice late albo-testaceis, arcu longo nigro, utrinque a humero usque ad marginem pone medium, suturam haud attingente, maculas pallidas marginales includente, et postice fascia obliqua pallida marginata; elytris lateribus impunctatis; pedibus rufo-fulvis.

Long. 6-7 lin.

Hab.-Tapajos and Ega.

In Tapajos examples only, the thorax is black, with reddish margins.

\section{Gnomidolon simplex.}

Ibidion simplex, White, Cat. Longic. Brit. Mus. p. 230.

Angustissimum, lineare, politum, nigro-piceum, sparse pilosum; elytris testaceo-fulvis, linea arcuata fusca, a medio baseos prope ad marginem lateralem pone medium, suturam haud attingente, maculam marginalem pallidam includente, apice indeterminate albo-testaceis; antennis (articulis 3 basalibus nigro-piceis exceptis) pallidis; pedibus elongatis, fulvo-testaceis, femoribus posticis dimidio apicali nigris.

Long. $3 \frac{1}{2}-4 \frac{1}{2}$ lin. $\delta$ o .

Hab.-Forest of Altar do Chaô, Tapajos ; common. 


\section{Gnomidolon dubium, n. sp.}

G. simplici valde affine, differt statura majore, linea fusca elytrorum postice apud discum terminante; tibiis intermediis tarsisque nigris; elytris obscurioribus.

Long. 5 lin. $\delta$.

Hab.-Tapajos.

\section{Genus Octoplon.}

Thomson, Syst. Ceramb. p. 218.

Hinder thighs slightly and gradually thickened, neither linear nor clavate, both the intermediate and posterior with two short equal or subequal spines at the tip. Thorax tuberculate, clothed with silvery tomentum.

I think this genus may be better limited to the second section, as characterized by Lacordaire, Gen. viii. 331, note.

\section{Octoplon Orpa.}

Ibidion Orpa, White, Cat. Longic. Brit. Mus. p. 227.

"Thoracis dorso monticuloso, antice nigerrimo, lævi, postice argenteo sericeo; elytris flavescentibus, fascia subapicali ferruginea, apice albis, mucronatis, lineola [obliqua] media nigra et arcu nigro basali." (White.)

Long. $5 \frac{1}{2}$ lin.

In the male, the third antennal joint is gradually thickened, and the fourth very much shorter than either the third or fifth. The thorax has five distinct large flattish tubercles. The elytra are polished, and without punctures, except the widely placed ones bearing long setæ, and which run in lines; the basal two-thirds are fulvous, then follows a broad reddish belt, and the apical part is testaceous yellowish-white; the basal fulvous portion is marked with a blackish curved line enclosing laterally a paler spot, behind this there is an oblique dark line, between which and the reddish belt is a paler fascia. The femora are elongate, the hind ones rather longer than the elytra, and armed with two short, distinct, nearly equal spines; the legs are pale testaceousred, the tips of the hindmost thighs dusky.

Hab.-River Tapajos. 


\section{Octoplon polyzonum, n. sp.}

Linear, head and thorax black, the latter very uneven, with the front and hind parts and sides very densely clothed with white tomentum, leaving an opaque portion in the middle, and two posterior tubercles black. Elytra pale tawny-brown, with five dark brown belts, the first very oblique near the shoulder, the second also oblique, much dilated towards the sutural end near the scutellum, the third straight, linear, and entire behind the middle, the fourth a little posterior to the third, much broader, rather paler and slightly oblique, and the fifth transverse, near the tip; behind the fifth belt, the elytra are testaceous-white, and between the third and fourth pale tawny; the surface is shining and impunctate, except a few setiferous punctures arranged in rows. Legs testaceous-tawny, hind thighs rather longer than the elytra, gradually but rather considerably thickened, the tips with two equal projecting broad spines.

Long. $5 \frac{1}{2}$ lin. ( $q$ ?, third joint of antennæ not thickened).

Hab.-River Tapajos. The fourth antennal joint is much shorter than the preceding and following.

\section{Octoplon tetrops, n. sp.}

Angustatum, thorace antice attenuato et constricto, capite valde exserto, collo distincto, rufo-testaceum ; capite subtiliter ruguloso et sericeo, oculis divisis ; thorace supra inæquali, longitudinaliter elevato, subnitido, plagiatim sparse tomentoso ; elytris postice attenuatis, supra seriatim sparse punctatis, fasciis duabus medianis approximatis, prima prope suturam interrupta, et apice late albo-testaceis; pedibus rufis, tarsis pallidioribus, femoribus sublinearibus, posticis apicem elytrorum attingentibus, breviter bidentatis; antennis et tibiis posticis carinatis.

Long. $4 \frac{1}{2}$ lin. 우.

The singular aberration in the form of the head amply distinguishes this species, as well as illustrates in a striking manner the instability of form of the most important organs in a genus of Longicorns; for the species, notwithstanding the division of the eyes into two on each 
side, and the dilatation of the cheeks behind the eyes, offers all the other characters of the Ibidiince. The thorax is more narrowed anteriorly than in most other species, and is constricted there, as well as near the hind margin. The antenniferous tubercles are obtus 3 , but the specimen is a $q$.

Hab.-Tapajos.

\section{Octoplon unoculum, n. sp.}

Cylindricum, longe pilosum, nigrum, nitidum; thorace flavo-griseo-pubescente, tuberculo discoidali nigro nitido; elytris postice valde convexis, ante medium fascia interrupta alba, dimidio apicali flavo-griseo-pubescente, antice albo-marginato, sparse punctatis, apice truncatis, extus breviter spinosis, spina alba; femoribus piceo-rufis, posticis elytris longioribus, apice distincte bispinosis ; antennis piceo-rufis, articulis 2 basalibus nigris, reliquis apice fuscis.

Long. $5 \frac{1}{4}$ lin. $q$.

An elegant species, of cylindrical from, distinguished by the single glossy black tubercle on the disc of the pubescent griseous thorax, and also by the convex posterior part of the elytra. The basal half of the elytra is glossy black, with very few punctures, and ornamented at about the third of the elytral length by a whitish belt, broadest on the lateral margin, and disappearing before reaching the suture; the apical half is covered with a dense griseous pubescence like that of the thorax, the anterior margin of this is advanced and rounded on the suture, and is there edged with whitish, which forms an indistinct, oblique, and entire fascia. The antennæ and tibiæ are carinate, and the hinder femora are nearly linear with distinct apical subequal spines.

Hab.-River Tapajos.

\section{Octoplon striatocolle.}

Ibidion striatocolle, White, Cat. Longic. Brit. Mus. p. 224 .

Elongatum, minus convexum, breviter sparse setosum, nigrum, nitidum ; thorace inæquali, transverse forte rugato, 
plagiatim argenteo-tomentoso; elytris utrinque ante medium macula discoidali et longe post medium fascia transversa marginem lateralem haud attingente fulvis, sparsim punctatis; femoribus paulo incrassatis, posticis elytris $\delta$ paulo longioribus, $q$ multo brevioribus, apice breviter bispinosis vel dentatis.

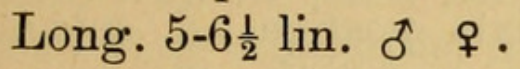

Distinguished by the numerous sharp transverse ridges across the disc and hinder part of the thorax. The basal joint of the antennæ is remarkably short, and arcuateclavate in form. In some specimens the femoral spines are very short, and do not project beyond the articulation of the tibiæ; the femora also approach the clavate form; the species stands, therefore, on the confines of the two groups Octoplon and Ibidion proper.

Hab.-Pará; also Cayenne, whence I have a specimen collected by M. Bar.

\section{Octoplon callispilum, n. sp.}

Elongatum, piceo-nigrum, nitidum, sparsim pilosum; thorace valde inæquali, quadri-tuberculato, et dorso spatio elevato, plagiatim argenteo-sericeo, impunctato, nitido; elytris basin versus plaga laterali magna intus rotundata et fascia lata pone medium antice ad suturam valde angulata testaceo-flavis, sparsim punctatis, apice longe unispinosis ; femoribus paulo incrassatis, distincte bispinosis ; antennis nigris, apicem versus sensim rufescentibus.

Long. $7 \frac{1}{2}$ lin. $q$.

The thorax is of similar elongate-cylindrical shape to the allied species, but is rendered unequal both on the sides and surface, by the sharp tubercles; the centre of the disc has an elongate flattish elevation, the two anterior tubercles of the disc are very acute; the pale markings of the elytra are very large, and leave between them a black cross-like mark, or rather, the space between the anterior lateral spot and the posterior broad fascia, forms a distinct oblique belt of the ground-colour of the elytra, open to the equally black base by the concolorous suture; the apex is black. The thighs are not at all clavate, and are distinctly bispinose, so that the species cannot come within the definition of Ibidion.

Hab.-Pará.

TRANS. ENT. SOC. 1870.-PART III. (AUGUST.) 


\section{Octoplon calligrammum, n. sp.}

Magnum, elytris haud linearibus, latis, apicem versus rotundato-attenuatis, piceo-nigrum, vix nitidum; thorace inæquali, tuberculato, sericeo-opaco et argenteo-tomentoso; elytris basin versus macula magna laterali subquadrata, et longe post medium fascia lata postice ad suturam indentata fulvis, supra passim punctatis, apice unispinosis; femoribus incrassatis, haud clavatis, apice bidentatis ; antennis piceis, apicem versus pallidioribus.

Long. 9 lin. + .

A large species, of much less linear figure than usual in this group. The elytra much wider, with the sides rounded, and tapering towards the apex; the thorax is very uneven, and projecting a little in the middle of the sides, but the tubercles are not distinct or acute; the whole surface is silky and sub-opaque. The elytra are thickly punctured throughout, and have short erect setæ; the spots are of very large size and fulvous; the space of ground-colour left between the anterior spot and the posterior fascia, forms a straight belt, owing to the fascia not being advanced on the suture, and the anterior spot being narrowed on the sides instead of widened.

Hab.-Ega.

\section{Octoplon cinctulum, n. sp.}

Minus elongatum, cylindricum, nigro-piceum, griseopilosum, vix nitidum, antennis, pectore et pedibus ferrugineis; thorace inæquali, medio paulo dilatato, tuberculo discoidali magno rotundato, sericeo-opaco; elytris punctis setiferis seriatim ordinatis et inter hæc punctulatis, basi rufescentibus, macula lineari transversa versus basin fasciaque angusta integra pone medium testaceo-flavis; femoribus paulo incrassatis, apice bidentatis.

Long. $3 \frac{1}{2}$ lin. $\delta$.

Of shorter form than its allies, linear or cylindrical. The thorax is silky and opaque, the elytra moderately shining, with very distinct setiferous punctures, and between them punctulate; the yellow marks are a transverse spot across the disc, not far from the base, and a narrow straight fascia considerably after the middle.

Hab.--River Tapajos. 


\section{Octoplon polychromum, n. sp.}

Elongatum, minus convexum; thorace valde inæquali, lateribus medio tumido et supra tuberculis quinque magnis, cum capite dense sericeo-tomentoso; elytris dimidio basali rufo, fascia obliqua versus basin (ad suturam late interrupta) testaceo-flava nigro-æneo-marginata, pone medium fascia testaceo-flava obliqua antice nigro-æneo-marginata, spatio apicali nigro-æneo, apice ipso testaceo-flavo, supra nitidis, punctis parvis setiferis ; antennis piceis; femoribus rufis, tibiis tarsisque nigris.

\section{Long. $6 \frac{1}{2}$ lin. 우.}

The design and colours of the elytra are much varied. Near the base is an oblique, moderately wide, yellowish fascia, which is far from reaching the suture, and is margined with brassy-black, this latter colour occupying the whole humeral space, leaving a spot of pale rufous only near the scutellum; behind the middle is an oblique and entire fascia, also of moderate but considerable width, margined anteriorly with brassy-black ; the whole space behind this is brassy-black, except the white tips; the whole surface is very glossy, and is roughened only by the setiferous punctures, which are very minute.

Hab.-River Tapajos.

\section{Octoplon carissimum.}

Ibidion carissimum, White, Cat. Longic. Brit. Mus.

$$
\text { p. } 223 \text {, pl. v. f. } 9 .
$$

"Pallide luteum lævissimum; capite, antennarum articulis duobus primis aterrimis; elytris, parte basali pallide lutea, macula alba, et postice fascia transversa, ornata, parte postica aterrima, apice extremo cum spinis albis." (White.)

Long. 4 lin.

Hab.-Pará.

This seems to be the position of this species, which, although taken by me, was not reserved for my own collection. 


\section{Octoplon rugicolle, n. sp.}

Lineare, breviter setosum, nitidum; thorace medio elevato et grosse transversim rugato, rufescente, antice cum capite obscuriori, lateribus sericeo-tomentoso; elytris apice unispinosis, angulo suturali producto, supra punctis setiferis sparsis, versus basin aspere tuberculatis, rufescentibus, tertia parte apicali nigra, macula indistincta versus basin alteraque recta transversa suturali communi testaceo-fulvis ; pedibus rufis, femoribus incrassatis, apice bidentatis.

Long. $4 \frac{1}{2}$ lin. $\$$.

Hab.-River Tapajos.

\section{Octoplon thoracicum.}

Ibidion thoracicum, White, Cat. Longic. Brit. Mus. p. 228.

Cylindricum, opacum, sparse setosum, pallide ochreum; thorace opaco, nigro, annulo magno per totam superficiem submarginalem rufo-testaceo et aureo-tomentoso ; elytris punctis setiferis asperatis, pallidis, fasciis angustis quinque pallide fuscis, duabus primis prope suturam conjunctis, spatio basali et inter fascias 4 tam et 5 tam pedibusque rufescentibus.

Long. $4 \frac{1}{4}$ lin. $\delta$.

The third antennal joint in the $\delta$ is gradually thickened, and is carinate, without grooves. The femora are much thickened and almost clavate, at the apices distinctly bidentate.

$$
\text { Hab.-River Tapajos. }
$$

13. Octoplon Rutha.

Ibidion Rutha, White, Cat. Longic. Brit. Mus. p. 227.

Cylindricum, capite rufo-testaceo, cinereo-tomentoso ; thorace inæquali, nigro, opaco, cinereo-tomentoso, punctis cinereis consperso, postice testaceo-rufo; elytris unispinosis, supra nitidis, sparsim longe fulvo-setosis, punctis setiferis asperatis, basi fulvo-brunneis, deinde fascia perobliqua a scutello ad medium marginis extensa 
testaceo-alba antice nigro-marginata, pone medium fascia testaceo-alba recta, et prope apicem fascia obscura fusca, spatio inter fascias primam et secundam nigro, inter hanc et fasciam tertiam fulvo-brunneo, spatio apicali testaceo-albo; antennis femoribusque fulvo-testaceis, his nigro-maculatis, femoribus posticis incrassatis, quasi clavatis, apice bidentatis; antennis articulo 3 to carinato et bisulcato ; tibiis posticis vix perspicue carinatis.

Long. $4 \frac{1}{2}$ lin.

Hab.-River Tapajos.

\section{Octoplon charile, n. sp.}

Elongatum, lineare, opacum ; capite testaceo-rufo, vertice nigro; thorace valde inæquali, tuberculoso, disco tuberculis minoribus setiferis sparsis, testaceo-rufo, sericeo-tomentoso, margine antico et disco nigris; elytris sordide testaceo-albis, passim punctulatis, punctisque setiferis asperatis, plaga magna scutellari alteraque minore prope apicem castaneis, pone medium fascia obliqua et paulo infra macula communi suturali nigris; antennis pallide rufescentibus, articulis $3-5$ forte sulcatis et carinatis; femoribus posticis paulo incrassatis, bidentatis, tibiis haud perspicue carinatis.

Long. 5 lin. $q$.

Hab.-River Tapajos.

\section{Genus Ibidion.}

Serville, Ann. Soc. Ent. Fr. 1834, p. 103 ; Lacord. Gen. viii. 331.

This genus is here restricted, following Lacordaire, to those species having the third antennal joint and posterior tibiæ carinate, and the hinder thighs distinctly or abruptly clavate and simple at their apices.

\section{Ibidion monostigma, $\mathrm{n}$. sp.}

Elongatum, elytris postice gradatim attenuatis, thorace antice constricto; castaneo-rufum, nitidum; thorace postice punctulato et sparsim tomentoso, medio dorsi 
transversim elevato et tri-tuberculato; elytris basi inæqualibus, apice unispinosis, punctis setiferis lineatim seriatis, macula magna oblonga ante medium, paulo obliqua, ochrea, fusco indeterminate marginata.

Long. $6 \frac{1}{2}$ lin. $\delta$.

Hab.-River Tapajos.

The legs are elongate, the hind femora (in the $\delta$ ) reaching a little beyond the apex of the elytra ; they are distinctly clavate, i.e., the base is slender, and towards the middle they become rapidly enlarged, so as to form an elongate club.

\section{Ibidion adicneme, n. sp.}

Elongatum, supra nigro-piceum ; thorace multi-tuberculato, opaco, argenteo-sericeo ; ely tris unispinosis, nitidis, punctis setiferis sparsis, macula rotundata utrinque versus basin, fascia obliqua pone medium alteraque recta apicali testaceo-albis; corpore subtus pedibusque rufo-piceis; antennis rufescentibus, basi nigris ; femoribus elongatis, abrupte tumide clavatis.

Long. 6 lin. $\delta$.

The thorax is very unequal on its sides and surface, partly caused by the transverse elevation across the anterior part having seven irregular tubercles; anterior and posterior to this, the thorax is constricted, and there are other tubercular elevations behind ; the whole surface is opaque, and clothed with silky tomentum. The white markings of the elytra are rather broad, and there is a wide space between the anterior rounded spot and the posterior fascia. The thighs are abruptly clavate, and the club tumid or dilated in the middle.

Hab.-St. Paulo, Upper Amazons.

\section{Ibidion rubellum, n. sp.}

I. cedicnemi valde affine, differt semper colore pallide fulvo-rufo, femoribus minus inflato-clavatis, elytris maculis flavis anticis majoribus antice versus basin extensis. Elongatum, fulvo-rufum; thorace opaco, argenteo-sericeo tomentoso, medio transversim elevato et multi-tuberculato; elytris macula ovata prope basin antice angus- 
tiori, fascia lata obliqua pone medium, apiceque testaceoalbis; femoribus clavatis.

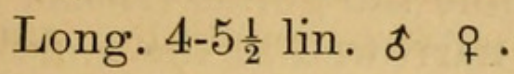

In the female, the antennal carinæ are with difficulty perceived, being visible only in certain lights, and unaccompanied by a groove.

Hab.-River Tapajos, Pará, Ega.

\section{Ibidion Leprieuri, n. sp.}

I. cedicnemi affine. Elongatum, capite thoraceque opacis, hoc argenteo-sericeo, antice transversim elevato et tuberculoso, disco postice bi-tuberculato; elytris apice extus unidentatis, supra politis, punctis setiferis paucis, obscure fulvo-brunneis, plus minusve fusco-plagiatis, macula magna ovali fusco-marginata versus basin, vitta lata obliqua pone medium (ad suturam angustata), et apice testaceo-albis ; antennis pallide rufescentibus, articulo 3io lateraliter vix perspicue carinato; femoribus fortiter clavatis.

Long. $5 \frac{1}{2}=6$ lin. $q$.

Hab.-Obydos, Lower Amazons; also Cayenne.

Received from Paris, under the MS. name here adopted.

\section{Ibidion dilectum, $\mathrm{n} . \mathrm{sp}$.}

Elongatum, testaceo-rufum, fulvo-setosum; capite piceo; thorace dorso quinque-tuberculato, argenteo-sericeo; elytris unispinosis, nitidis, parte basali ultra medium fulva, parte apicali nigra, macula magna rotundata versus basin, vitta obliqua pone medium, apiceque testaceo-albis; antennis (articulo basali piceo excepto) et pedibus pallide testaceo-rufis; pedibus elongatis, femoribus abrupte clavatis.

Long. $4 \frac{1}{4}$ lin. $\delta$.

Hab.-Ega.

\section{Ibidion digrammum, $\mathrm{n} . \mathrm{sp}$.}

Elongatum, rufo-castaneum, nitidum; thorace medio valde angustato, medio dorsi bispinoso, postice bituberculato; elytris linea flava paulo obliqua discoidali ante medium. 
Long. $6 \frac{1}{4}$ lin. $\delta$.

One of the species which resemble the genus Gnoma in the curious form of the thorax narrowed in the middle. The whole surface is glossy, and of a reddish-chesnut hue. On the middle of the thorax are two small spines or very acute tubercles, and behind, near the hind margin, are two obtuse rounded tubercles. The yellow lines on the elytra are about one-fifth the length of the wingcases, and lie a little obliquely, the lower end being near the suture.

Hab.-River Tapajos.

\section{Ibidion sulcicorne.}

White, Cat. Longic. Brit. Mus. p. 232.

Elongatum, robustum, ferrugineum; thorace æquali, nudo, opaco ; elytris nitidis, passim punctulatis, apice unispinosis, toto disco nigricante, linea longitudinali ante medium suturæ parallela, altera pone medium obliqua pallidis; pedibus robustis, femoribus grosse clavatis; antennis $\left(\delta^{\star}\right)$ articulo 3io reliquis latiori et cum 4 to et 5 to carinato et bisulcato.

Long. 6 lin. $\delta$.

Hab.-River Tapajos.

\section{Ibidion sphariinum, n. sp.}

Facies Peribci (Sphcriinarum), castaneo-fuscum, nitidum ; capite grosse confluenter punctato ; thorace elongato, medio paulo latiori, subnitido, tenuiter tomentoso, punctulato et punctis nonnullis magnis setiferis; elytris apice sinuato-truncatis, bispinosis, spina suturali minori, supra politis, punctis setiferis seriatim ordinatis, interstitiis sparsim punctulatis; antennis sparsim setosis, articulis 3 io et 4 to carinatis; pedibus curtis, femoribus valde clavatis.

Long. $4 \frac{1}{2}$ lin. $q$.

In its shining concolorous dark chesnut hue, without pale markings, and its bispinous elytra, this resembles species of Periboum in the sub-family Sphceriince, but is readily distinguished by the unarmed antennæ. The 
elytra taper a little from the base to the extremity, the hind thighs are very much shorter than the apex of the elytra, but the specimen is most likely a female.

Hab.-St. Paulo, Amazons.

\section{Ibidion unicolor.}

White, Cat. Longic. Brit. Mus. p. 233.

Parvum, angustum, lineare, castaneo-rufum, nitidum; capite impunctato; thorace cylindrico, æquali, lævi; elytris apice bispinosis, spina exteriori valde elongata obliqua, supra passim punctulatis, haud setosis ; femoribus modice elongatis, clavatis.

Long. $2 \frac{3}{4}$ lin. ( 9 ?).

Hab.-River Tapajos.

\section{Ibition lineolatum, n. sp.}

Elongatum, lineare, angustum, setis perpaucis vestitum, castaneum, politum ; capite et thorace sericeis, punctulatis, hoc cylindrico, æquali; elytris apice sinuato-truncatis et bispinosis, spina exteriori majori recta, supra politis, punctulatis (apice lævibus), medio utrinque lineola discoidali elevata alba, suturæ parallela, extus late nigromarginata; antennis articulis $3-5$ paullo incrassatis et infra longissime ciliatis ; femoribus abrupte clavatis.

Long. $4 \frac{1}{4}$ lin. ( $\delta^{\pi}$ ?).

Hab.-Ega.

\section{Genus Compsa.}

Perty, Del. An. Art. Bras. p. 92; Lacord. Gen. viii. 333.

Characters of Ibidion, with the exception that the hinder tibiæ have no trace of carinæ. It seems to me preferable to limit the genus to those species in which the third joint of the antennæ is carinate, leaving those in which there is no trace of carina either on the antennæ or tibiæ in the genus Heterachthes. 


\section{Compsa basalis.}

Ibidion basale, White, Cat. Longic. Brit. Mus. p. 229.

Elongata, testaceo-ferruginea, fusco-variegata, griseo longe setosa; antennis pallidis, articulis 1-4 nigris, $3-4$ ( 8 ) incrassatis ; thorace dorso tuberculis quinque magnis rugosis nigris, interstitiis argenteo-tomentosis; elytris unispinosis, supra nitidis, tuberculis setiferis sparsim asperatis, disco longitudinaliter depressis, lateribus indeterminate albo-testaceis, medio vitta irregulari obliqua a humeris ad suturam pone medium, maculisque subapicalibus nigris; femoribus clavatis et cum corpore subtus rufo- et nigro-variegatis.

Long. 4-4 $\frac{3}{4}$ lin. $\delta$.

Closely allied to Octoplon Rutha, charile, \&c. (ante, p. 297 ), in form and in the peculiar coloration.

Hab.-River Tapajos.

\section{Compsa histrionica, n. sp.}

Elongata, pallide fulvo-rufa; thorace valde inæquali, multi-tuberculato et tuberculis setiferis consperso, nigrovariegato, opaco; elytris pallide testaceo-fulvis, basi rufescentibus, fascia curvata prope basin, alteris duabus tenuibus undulatis pone medium, et quarta obliqua posteriori nigris, apice unispinosis; antennis pallidis, articulis 4 basalibus nigris ; femoribus clavatis, fusco-testaceis, tibiis tarsisque pallidis.

Long. 5 lin. + .

Belongs to the same natural group as $C$. basalis, Octoplon Rutha, \&c., but from the absence of tibial carinæ, coming within the definition of the genus Compsa. The thorax is much shorter in comparison with the elytra than in the allied species. The dark markings of the elytra consist of an oblique belt, commencing at the shoulder, and bending down to the suture, not very far from the scutellum; then, beyond the middle follow two slender, parallel, undulate belts, oblique in an inverse direction to the basal belt, and immediately behind these is a fourth belt, oblique in the same direction as the basal one, namely, from the lateral margin backward to the suture; this last belt gradually widens as it approaches the suture. The specimen is a female; in the male the third and fourth antennal joints are probably thickened. Hab.-Ega. 


\section{Compsa quadriguttata.}

Ibidion quadriguttatum, White, Cat. Longic. Brit. Mus. p. 226 .

Angustata, linearis, fulvo-testacea, capite thoraceque griseo-tomentosis ; hoc cylindrico, paulo inæquali, haud tuberculoso, lævi; elytris sinuato-truncatis et bispinosis, nitidis, lævibus, punctulis setiferis vix conspicuis, fulvis, macula obliqua lineari laterali prope basin, alteraque simili prope apicem nigris, testaceo-albo-marginatis.

Long. 4 lin. $q$.

Hab.-River Tapajos.

Genus Heterachthes.

Newman, Entom. i. 9.

Compsa (part), Lacord. 'Gen. viii. 333.

Antennæ and tibiæ free from carinæ; the femora are clavate, and destitute of spines at the tip. Notwithstanding these differences of structure, the species offer no peculiarity of facies to distinguish them from Ibidion, Gnomidolon, and other sub-divisions.

\section{Heterachthes decipiens, n. sp.}

Elongatus, nigro-piceus, nitidus, setosus, antennis femoribusque rufo-piceis ; thorace elongato, angusto, polito, lævi, dorso medio tuberculo magno conico; elytris bispinosis, spina suturali minori, supra (punctulis setiferis exceptis) lævibus, macula laterali ante medium fasciaque obliqua paulo post medium testaceo-flavis.

Long. $4 \frac{1}{4}$ lin. $\delta$ \% .

This species has a very close resemblance to Gnomidolon melanosomum (ante, p. 288) and the allied species, but differs in the antennal joints being entirely free from carinæ in both sexes; the third joint is perfectly cylindrical. In the $\delta$, the third to the sixth joints are a little stouter than in the $q$; in the femora, the club is distinct, but not abruptly formed, and the slight projections at the apex are not sufficiently advanced or pointed to be termed spines or teeth.

Hab.-Ega. 


\section{Heterachthes corallinus, n. sp.}

Elongatus, postice attenuatus, rufus, nitidus, elytris fascia lata basali alteraque simili apicali nigro-æneis; antennis articulis a 3 io ad 5 tum et 6 to basi paulo incrassatis ; thorace paulo inæquali, polito, lævi; elytris apice utrinque in spinam prolongatis, supra punctis setiferis seriatim ordinatis ; femoribus clavatis.

Long. 4 lin. 8 .

A brilliantly-coloured and elegant species ; distinguished besides by the elytra not being truncate at the apex, but tapering each into a spine.

Hab.-River Tapajos.

\section{Heterachthes involutus, n. sp.}

Elongatus, minus cylindricus, castaneo-rufus, setosus, nitidus ; capite dense punctato ; thorace minus elongato, medio paulo dilatato, supra plagiatim punctato, linea dorsali abbreviata elevata, vittis duabus nigro-fuscis; elytris apice breviter truncatis, extus unidentatis, supra lævibus (punctis setiferis exceptis), usque ultra medium fulvis, linea arcuata a margine sub humero incipiente et ad marginem ultra medium terminante suturam vix attingente et parte anteriore incrassata fusco-castanea, triente apicali etiam fusco-castanea; femoribus posticis ( $\delta$ ) apicem elytrorum haud attingentibus.

Long. 4-6 $\frac{1}{2}$ lin. $\delta$ o .

Hab.-River Tapajos.

\section{Heterachthes longipilis, n. sp.}

Elongatus, longe griseo-pilosus, rufo-castaneus, nitidus ; thorace supra quinque-tuberculato, tenuiter plagiatim griseo-tomentoso, haud opaco; elytris ante apicem rotundatis, apice sinuato-truncatis bispinosis, spinis subæqualibus, supra (punctulis setiferis exceptis) lævibus, vitta sub-recta a basi prope ad medium, fascia valde obliqua pone medium, apiceque flavo-testaceis ; femoribus utroque sexu apicem elytrorum longe haud attingentibus, clavatis; antennis longe pilosis, articulis a 3io ad 5 tum ( $\delta$ ) paulo crassioribus.

Long. $4 \frac{1}{4}-5 \frac{1}{4}$ lin. $\delta$ 우 .

Hab.-River Tapajos. 


\section{Heterachthes agrotus, n. sp.}

Angustatus, linearis, pallide testaceus, longe setosus ; thorace supra quinque-tuberculato, argenteo-griseo tomentoso, nitidulo ; elytris apice oblique truncatis, angulis haud productis, supra nitidis, passim haud profunde punctatis et punctis setiferis conspersis, macula triangulari communi basali alteraque simili subhumerali pallide rufescentibus, fascia obliqua pone medium, altera recta transversali prope apicem, apicibusque albo-testaceis; femoribus elongatis, gradatim sed distincte clavatis.

Long. 4 lin. $\delta$.

Hab.-Ega.

\section{Heterachthes sylphis, n. sp.}

Gracilis, linearis, capite thoraceque angustioribus, rufo-castaneus, nitidus ; capite fortiter punctato, tuberibus antenniferis obtusis; thorace angusto, elongato, vix inæquali, nitido, postice subtiliter punctulato; elytris subplanis, apice oblique truncatis, angulis haud productis, supra (punctulis paucis setiferis exceptis) lævibus, fascia lata transversa recta ante medium alteraque simili apicali flavo-testaceis; antennis pallide rufo-testaceis, articulo 3io of incrassato; pedibus elongatis, femoribus clavatis longissimis, posticis apicem elytrorum multo superantibus.

Long. $3 \frac{1}{2}$ lin. $\delta$.

Differs wholly in facies from the majority of the genus which have short femora.

Hab.-River Tapajos.

\section{Heterachthes deliciolus, n. sp.}

Gracilis, linearis ; capite piceo-rufo, subnitido; thorace valde inæquali, supra quinque-tuberoso, nigro-piceo, sericeo-opaco, argenteo-tomentoso; elytris apice sinuatotruncatis, angulis paulo productis, supra (punctulis setiferis exceptis) lævibus, nitidis, castaneis, macula magna utrinque basali, fascia lata pone medium ad suturam antice dilatata, apicibusque testaceo-albis, parte basali pallide fulva; pedibus antennisque fulvis, femoribus clavatis, modice elongatis.

Long. $3 \frac{1}{2}$ lin. ( 9 ?).

Hab.-Obydos, Lower Amazons. 


\section{Genus Cycnidolon.}

Thomson, Syst. Eeramb. p. 217 ; Lacord. Gen. viii. 333.

The third and sometimes the fourth antennal joints in the $\delta$ are greatly thickened, fusiform or oval, and carinate in both sexes; femora abruptly clavate, and the hind pair bidentate at the apex; tibiæ carinate.

\section{Cycnidolon Batesianum.}

Ibidion Batesianum, White, Cat. Longic. Brit. Mus. p. 230, pl. vi. f. 6 .

Cylindricum, nigro-fuscum; elytris dimidio apicali cinereo-pubescenti, antice fascia tenui testaceo-alba marginato, dimidio basali nitido, macula triangulari laterali ante medium, apice longe unispinosis; antennis pallide rufo-testaceis, articulo 3io a basi gradatim incrassato, 4to ovato ( $\delta$ ); pedibus testaceo-rufis.

Long. $3 \frac{1}{4}$ lin. $\delta$.

I do not find a female example of this species among my series.

Hab.-River Tapajos and Ega.

\section{Cycnidolon binodosum, n. sp.}

C. Batesiano valde affine; differt ( $\delta$ ) articulo 3 io antennarum basi pedunculato abrupte clavato, 4to etiam clavato sed pedunculo breviori ; elytrorum fascia obliqua albo-testacea a parte cinerea bene distante.

Long. $2 \frac{3}{4}$ lin. $\delta$.

Hab.-Ega.

\section{Cycnidolon approximatum.}

Ibidion approximatum, White, Cat. Longic. Brit. Mus, p. 231 .

A $C$. Batesiano differt articulo 4to antennarum haud inflato, lineari, macula fasciaque elytrorum apud latera approximatis, a plaga postica cinerea distantibus.

q. Articulis 3-4 antennarum linearibus. 
Long. $3 \frac{1}{2}$ lin. $\delta$ q .

Hab.-River Tapajos, Ega, St. Paulo, Upper Amazons.

\section{Genus Phormesium.}

Thomson, Syst. Ceramb. p. 217 ; Lacord. Gen. viii. 335.

Differs from all the preceding genera of Ibidionince in the short antennæ, scarcely longer than the body in the $f$, shorter in the $q$. The third and fourth antennal joints and the tibiæ are carinate; the femora are clavate, shorter than the elytra, and bidentate at the apex. The carinæ of the antennæ are sometimes very faint, and scarcely perceptible. The third antennal joint is fusiform in the $\delta$.

\section{Phormesium melanodacrys.}

Ibidion melanodacrys, White, Cat. Longic. Brit. Mus. p. 235.

"Parvulum, flavo-testaceum, elytris singulis guttis duabus nigris marginalibus, primâ pone humerum, secundâ ad medium, antennis articulo tertio incrassato." (White.)

Long. $2 \frac{1}{2}$ lin. $\delta$ o .

Hab.-River Tapajos.

All the antennal joints are carinate from the third to the tenth. The black "guttæ " of the elytra are linear, lateral, and oblique; the surface is polished, and almost impunctate.

\section{Phormesium albinum, n. sp.}

Elongatum, angustum, nitidum, longe setosum, flavotestaceum ; elytris fasciis duabus obliquis testaceo-albis, una versus basin (suturam haud attingente), altera apud medium; thorace medio tri-tuberculato, polito; elytris sinuato-truncatis, extus spinosis ; antennis vix perspicue carinatis.

Long. 3 lin. $q$.

Hab.-River Tapajos. 
Genus Aphatum, nov. gen.

Corpus lineare. Oculi laterales, supra valde distantes ; tubera antennifera rotundata, late separata. Antennæ corpore breviores, filiformes, articulis nec incrassatis nec carinatis, quarto brevissimo. Thorax elongatus, supra subplanus, antice latior, haud constrictus, postice gradatim attenuatus. Elytra apice utrinque longe bispinosa. Pedes breves, femora clavata, apice bidentata, tibiæ haud carinatæ.

Allied to Phormesium, but differing from it, as from all other genera of Ibidionince, in the form of the thorax, which is wider in front than behind, and has no trace of constriction, except near the hind margin. The widely distant eyes, and short antennæ, which are exactly filiform, i.e. are as thick at the apex as at the base (except the first joint), also distinguish the genus.

\section{Aphatum rufulum.}

Ibidion rufulum, White, Cat. Longic. Brit. Mus. p. 234.

Parvulum, rufo-testaceum, parce pilosum, nitidum; thorace elytrisque (punctis setiferis exceptis) lævibus.

Long. $2 \frac{3}{4}$ lin.

Hab.-River Tapajos.

Sub-fam. OBRIINæ.

Genus Obrium.

Serville, Ann. Soc. Ent. Fr. 1834, p. 93 ; Lacord. Gen. viii. 361.

1. Obrium cordicolle, $\mathrm{n}$. sp.

Pallide flavo-testaceum, passim pilosum, nitidum; capite subtiliter rugoso-punctato; thorace lateribus antice valde dilatato vel tumido, postice constricto, supra polito, lævi, dorso depresso; elytris apice rotundatis, supra (punctis piliferis exceptis) lævibus, punctis, fascia tenui prope basin, secunda antice arcuata pone medium, tertiaque arcuata sensu inverso prope apicem, pallide fuscis ; femoribus clavatis. 
Long. $2 \frac{1}{4}$ lin.

Closely allied in form and colours to an undescribed species from Texas. The pale brown fasciæ of the elytra form very slender lines, the second fascia is arcuate towards the base, the third towards the apex, so that the two together form a large ring on the apical half of the two elytra. The abdominal segments in the $q$ are distorted in a similar way to the European types of the genus.

Hab.-Santarem, Amazons.

\section{Genus Armotis.}

Bates, Entom. Monthly Mag. iv. 26 (1867) ; Lacord. Gen. viii. 398.

(Charac. emend.). Corpus lineare, tenue. Caput supra inter antennas planum, ultra oculos paulo prolongatum, attenuatum ; oculi distantes; palpi breves, apice truncati; antennæ (ふ) corpore dimidio longiores, tenues, filiformes, breviter sparsim setosæ, articulo basali elongato, leviter incrassato, articulis 3-11 longitudine subæqualibus, simplicibus. Thorax angustus, elongatus, medio paulo dilatatus, lateribus subtuberculatus. Elytra linearia, plana, apice rotundata. Pedes elongati, graciles; iemora abrupte clavata, postica longe ultra apicem elytrorum extensa. Coxæ anticæ globulosæ, exsertæ. Acetabula intermedia extus aperta, mesosterni epimera angusta. Abdominis segmenta of normalia, primo magis elongato.

This genus, the position of which Lacordaire considered doubtful, appears to belong to the group Obriince, with the species of which it also agrees in facies.

\section{Arceotis fragilis, Bates, $l, c$.}

Flavo-testacea, opaca, supra nuda, articulis antennarum apice fuscis; capite thoraceque creberrime punctulatis ; elytris alutaceis et passim punctatis; pedibus breviter setosis.

Long. $2 \frac{1}{2}$ lin. $\delta$.

Hab.-River Tapajos.

TRANS. ENT. SOC. 1870.-PART III. (AUGUST.) 


\section{Genus Dodecosis.}

Bates, Entom. Monthly Mag. iv. 27 (1867); Lacord. Gen. viii. 398.

(Charac. emend.). Corpus subcylindricum. Caput antice verticale, breve, tuberibus antenniferis elevatis, supra acutis ; palpi brevissimi, apice truncati, vix securiformes; antennæ corpore duplo longiores, filiformes, robustæ, distincte 12-articulatæ, longe pilosæ, articulo $1 \mathrm{mo}$ brevi claviformi, 3io paulo 4to breviori, a 4 to ad 12 mum æqualibus, simplicibus. Thorax cylindricus, elytris multo angustior, inermis, antice et postice transversim impressus. Elytra linearia, apice breviter truncata. Pedes modice graciles, femoribus paulo incrassatis. Prosternum inter coxas angustum; coxis exserto-conicis, extus angulatis; acetabula intermedia extus aperta.

This genus seems not to fit into any of the sub-families or "groupes" into which Lacordaire has divided the Cerambycidce. In its completely 12-jointed and excessively short antennæ, and perpendicular forehead, it is unlike any other genus known to me. In facies, however, it resembles somewhat the Obriince, and it seems less out of place in this sub-family than in any other.

\section{Dodecosis saperdina, Bates, $l$. c.}

Fulvo-testacea, sub-opaca, longe tenuiter pilosa; antennis (articulo primo excepto) fusco-nigris, articulis basi pallidis ; fronte convexa; thorace lateribus antice breviter tuberculato, disco paulo elevato ; elytris dense punctulatis, sutura margine laterali carinaque dorsali ante apicem desinente elevatis.

Long. $3 \frac{1}{2}$ lin. 8 .

Hab.-River Tapajos.

One example only.

The insect resembles, in its general shape, and to some extent in the filiform antennæ, certain slender species of Saperdince. 
Section B. Eyes finely facetted.

Sub-fam. Lepturine.

Genus Ophistomis.

Thomson, Archiv. Entom. i. 319; Lacord. Gen. viii. 451.

\section{Ophistomis bivittatus, $\mathrm{n} . \mathrm{sp}$.}

đ. Gracilis, postice valde attenuatus, luteo-flavus, breviter setosus; antennis longitudine corporis, a medio usque ad apicem incrassatis, nigris ; capite thoraceque nigrobivittatis, crebre punctatis, illo vertice etiam nigro; elytris humeris obtusis, postice incurvatim attenuatis, apice oblique truncatis et bidentatis, supra passim punctatis, punctis setiferis, setis incumbentibus, sutura, margine basali, macula laterali apud medium, fasciisque duabus posticis (secunda apicali), nigris ; femoribus apice, tibiis tarsisque nigris; abdomine rufo, coxis posticis et metasterni episterno nigro-maculatis.

ㅇ a $\delta$ valde differt. Robustior, humeris multo latioribus, fulvus; antennis dimidium corporis paulo superantibus, articulis 5 basalibus fulvis, reliquis nigris, incrassatis; capite thoraceque nigro-bivittatis, crebre punctatis, hoc linea dorsali lævi; elytris humeris latis rotundatis, postice recte attenuatis, apice oblique truncatis et bidentatis, supra punctulatis et setosis, utrinque sutura, maculis tribus discoidalibus, alterisque duabus minoribus juxta humeros, nigris; pedibus fulvo-rufis, apicibus femorum tibiarumque posticarum, et tarsis nigris.

Long. 7 lin. $\delta$ $q$.

Hab.-Ega ; many examples.

Like all other species of Ophistomis, it is found in the forest, slowly flying about the underwood in fine weather, and settling on the slender stems of climbing and other plants ; sometimes the species are seen on flowers.

\section{Ophistomis paraensis, n. sp.}

万. 0 . bivittato valde affinis, differt colore magis fulvo, et elytris apice haud nigro-fasciatis. Gracilis, 
fulvus, punctatus, setosus ; capite thoraceque nigro-bivittatis ; elytris valde attenuatis, sutura, margine basali, vitta laterali ante medium, fasciaque pone medium, nigris; femoribus apice, tibiis, tarsis, maculisque pectoris nigris.

†. Ignota.

Long. $6 \frac{1}{2}$ lin.

Hab.-Pará.

\section{Ophistomis ochropterus, n. sp.}

§. Gracilis, postice gradatim lateribus haud incurvatim attenuatus, fulvo-ochraceus, flavo-setosus, punctulatus, haud nitidus ; antennis a medio modice incrassatis, nigris ; epistomate, vertice, maculaque magna antico-dorsali thoracis nigris; elytris marginibus apicibusque nigris; pedibus nigris, femoribus antice subtus flavo-testaceis; abdomine apice nigro.

Long. $4 \frac{1}{2}-6 \frac{1}{2}$ lin.

Hab.-Ega.

\section{Ophistomis melanostomus, n. $\mathrm{sp}$.}

․ Robustior, postice minus attenuatus, fulvo-testaceus, subnitidus, epistomate, vertice, maculaque magna anticodorsali thoracis nigris, hoc minus crebre, vertice creberrime punctatis ; antennis a medio vix incrassatis, piceorufis, basi et apice fuscis; elytris vittis suturali et marginali (hac in fascia ante-apicali terminata) apicibus que nigris; pedibus nigris, femoribus dimidio basali fulvis ; abdomine apice nigro.

Hab.-Ega.

Possibly the $q$ of Oph. ochropterus.

5. Ophistomis rubricollis, n. sp.

q. Curtus, robustus, postice attenuatus, niger, thorace læte rufo; antennis apicem versus paulo incrassatis; thorace creberrime punctato, opaco; scutello rufo; elytris margine basali rufescente, crebre punctatis, subnitidis.

Long. 5 lin.

Hab.-Ega. 
6. Ophistomis semifulvus, n. sp.

+ . Minus elongatus, postice vix attenuatus, fulvorufus; elytris (margine basali maculaque humerali exceptis) nigris; antennis vix incrassatis; thorace crebre punctato, linea dorsali lævi ; apicibus femorum, tibiarum et tarsorum nigris.

Long. $4 \frac{1}{2}$ lin.

Hab.-Ega.

7. Ophistomis albicollis.

Euryptera albicollis, Pascoe, Journ. Entom. i. 63.

Elongatus, niger, thorace (vitta dorsali excepta) maculaque elongata elytrorum testaceo-flavis ; capite testaceoflavo, epistomate nigro-plagiato; antennis articulis basi, coxis femoribusque plus minusve testaceis.

ऽ. Gracilis; antennis longitudine corporis, apicem versus vix incrassatis; elytris medio paulo angustatis, ante apicem paululum iterum dilatatis.

우. Robustior; antennis dimidium corporis paulo superantibus, medio (haud apicem versus) incrassatis; elytris elongatis, parallelogrammicis, ante apicem paululum rotundatis.

Hab.-St. Paulo, Amazons.

The form of the rostrum, and the terminal ventral segment of the male, demonstrate that this species belongs to Ophistomis rather than to Euryptera.

\section{Genus EuRyptera.}

Serville, Encycl. Meth. x. 688 ; Lacord. Gen. viii. 454.

\section{Euryptera atripennis, n. sp.}

Curta, postice paululum dilatata, punctata, pubescens, subnitida, fulvo-rufa, elytris (macula humerali excepta) nigris, tibiis tarsisque posticis fuscis; antennis robustis, medio paulo incrassatis; capite antice satis elongato et angustato, epistomate punctato polito; thorace minus dense punctulato; elytris ante apicem paulo rotundato- 
dilatatis, apice late vix oblique truncatis, extus spinosis, supra linea elevata prope suturam, griseo-pubescentibus subnitidis; pedibus robustis, tarsis posticis curtis, tibiis multo brevioribus; abdomine (segmento basali rufo excepto) nigro, segmento ultimo ventrali apice truncato, angulis longe spinosis.

\section{Long. $4 \frac{1}{2}$ lin. ( $q$ ?).}

In the form of the terminal ventral segment, and the shortness and stoutness of the hind tarsi, this species agrees with $E$. latipennis, Serv.

Hab.-Ega.

Sub-fam. Necydaline.

Genus Sphecomorpha.

Newman, Entom. Mag. v. 396; Sphecogaster, Lacord. Gen. viii. 471 .

1. Sphecomorpha chalybea, Newman, l.c. Sphecogaster biplagiatus, Lacord., lib. cit. p. 472, n. (?).

"Chalybeo-nigra; antennis nigris, articulis 4 to et 5 to subtus testaceis; elytris vitta subhumerali maculaque dorsali albidis, hac fascia ænea transversa divisa."

Long. 13 lin.

Hab.-Ega.

This bears the closest resemblance to a large wasp of the genus Epipone, and was captured by me as such, flying in the forest at Ega; it was only after examination at the bottom of my net, that I found it was not a wasp. Subsequently I saw three examples at myrtle blossoms, but by an unlucky shaking of a branch, missed them all, as they took to flight instantly.

Lacordaire appears entirely to have overlooked Newman's genus. I am inclined to think the species he describes is the same as Newman's.

Sub-fam. Molorchine.

Genus Stenoptrellus, nov. gen.

Merionodae et Stenoptero affinis; differt antennis (ㅇ) longitudine corporis, setaceis. Corpus tenue, de- 
pressum. Caput exsertum, angustum, antice paulo prolongatum et attenuatum; oculis paulo prominentibus; palpis brevibus, articulis terminalibus apice attenuatis truncatis; antennis pilosis, apicem versus attenuatis, articulis tenuibus, apice intus paulo productis. Thorax tuberosus, antice valde angustatus et forte constrictus. Elytra plana, abdomine quarta parte breviora, apicem versus attenuata et dehiscentia, apice obtuse acuminata. Pedes pilosi, postici longiores et robustiores; femora omnia abrupte clavata; tarsi breves. Coxæ anticæ conicæ, exsertæ. Abdomen ( $q$ ) segmento ventrali primo magno, integro, secundo paulo minori, postice semicirculariter emarginato et longe ciliato, reliquis profunde depressis.

\section{Stenoptrellus culicinus, n. sp.}

Niger, nitidus; thorace tuberibus octo inæqualibus, duobus medianis linearibus; elytris pallide ochreis, passim grosse punctatis, linea elevata laterali a medio usque ad apicem; abdomine segmentis duobus basalibus rufis.

Long. $3 \frac{1}{4}$ lin. $q$.

Hab.-Ega ; on flowers.

\section{Sub-fam. Necydalopsine.}

\section{Genus Sthelenus.}

Buquet, Ann. Soc. Ent. Fr. 1859, p. 621 ; Lacord. Gen. viii. 494.

\section{Sthelenus braconinus, n. sp.}

S. ichneumoneo (Buquet) affinis, differt thorace antice nigro, pedibus anticis et intermediis totis rufis. Linearis, testaceo-rufus, capite, antennis, plaga antica thoracis, postpectore, femoribus posticis apice, tibiis tarsisque nigris ; elytris pallidis, fascia paulo post medium fusca.

Long. 5-7 lin. $\delta$ o .

Hab.-St. Paulo, Amazons.

Resembling to deception certain common species of Bracon, Fam. Ichneumonidae. Found flying at mid-day on low bushes; the limbs, as in Ozodes and the Clyti, are extremely fragile, breaking off almost at a touch. 
Sub-fam. Rhinotragine.

Genus Oxylymma.

Pascoe, Trans. Ent. Soc., 2 ser., v. 21 ; Lacord. Gen. viii. 500 .

1. Oxylymma lepida. Pascoe, lib. cit. p. 22, pl. ii. f. 3.

Testaceo-flava, glabra, nitida, vertice, antennarum basi, fasciis duabus elytrorum, maculaque triangulari humerali, nigris ; elytris acuminatis, fortiter punctatis.

Long. $5 \frac{1}{2}$ lin. $q$.

Hab.-Ega.

\section{Oxylymma telephorina, n. sp.}

Elongata, passim pallide setosa, flavo-testacea, capite supra maculisque humeralibus posticisque elytrorum nigris ; capite rostro valde abbreviato, antice et partibus oris flavis, supra cum collo nigro, grosse sparsim punctato ; antennis testaceo-flavis; thorace ovato, postice constricto, supra antice grosse ( $q$ minus) punctato ; elytris apice obtuse rotundatis, angulo suturali paulo producto, supra dense punctatis, macula humerali per marginem continuata, alteraque transversa prope apicem (interdum obsoleta), nigris ; postpectore nigro.

Long. $4 \frac{1}{2}-5$ lin. of $q$.

Differing from $O$. lepida in the anterior part of the head not being prolonged into a muzzle, but moderately short. Notwithstanding this important difference, it can scarcely be placed in a separate genus, as almost every other character of the insect agrees with Oxylymma; it has the same peculiar form of the head, eyes, insertion of the antennæ, thorax, and legs.

Hab.-Ega.

Genus Erythroplatys.

White, Cat. Longic. Brit. Mus. p. 201; Lacord. Gen. viii. 511.

Lacordaire doubts whether this genus can belong to the Rhinotragina; but in all essential points of structure it 
has the closest affinity with Rhinotragus. The middle sockets are widely open externally, and the mesosternum has elevated and acute lateral margins, and is vertical anteriorly. The metasternum is large and inflated.

\section{Erythroplatys corallifer.}

White, Cat. Longic. Brit. Mus. p. 202, pl. v. f. 2.

The figure here quoted will give an accurate idea of this singular insect, which by reason of its widely-dilated elytra, coarse sculpture, and bright red and black colours, becomes the mimetic analogue of Cephalodonta spinipes, Fabr., of the family Hispidae. It is not found, however, in company with that insect. At least, the few examples I met with were found on the flowers of a low tree, named Pitomba, in the neighbourhood of Santarem, whilst the Cephalodonta was seen only on the foliage of a climbing plant, generally in great numbers.

\section{Genus Rhinotragus.}

Germar, Ins. Sp. Nov. p. 513 ; Lacord. Gen. viii. 500.

1. Rhinotragus trilineatus.

White, Cat. Longic. Brit. Mus. p. 200.

"R. flavus; antennis, capite, thoracis maculis duabus dorsalibus, lineis tribus elytrorum, una suturali, pedibus femorumque basi exceptis, abdomine apice, nigris." (White.)

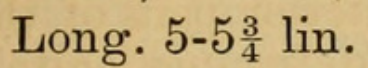

Distinguished from the typical species of Rhinotragus by its more slender form, the elytra narrowing more towards the apex, and by its slender antennæ; but agreeing with them in the glossy elevations of the thorax, the swollen lateral rim of the elytra, and the distinctly serrate antennæ.

Hab.-Villa Nova, Amazons ; on flowers.

\section{Genus Agaone.}

Pascoe, Trans. Ent. Soc., 2 ser., v. 22.

Lacordaire unites this genus to Ommata; from which, it appears to me distinct in the short, slender, filiform antennæ, the short cylindrical thorax, and the much shorter 
legs, especially the hind pair. It forms a very natural assemblage of small delicate species, all having the same style of colouring. The thorax is free from glossy elevations, and is thickly punctured.

\section{Agaone notabilis.}

Rhinotragus notabilis, White, Cat. Longic. Brit. Mus. p. 199.

"R. luteus; antennis nigris, articulis 8 ultimis basi flavis ; thorace macula magna dorsali nigra ; elytris nigris, singulis vitta elongata basali et fascia transversali subapicali sulphureis; pedibus nigris, femoribus basi et apice intus flavis." (White.)

Long. $3 \frac{3}{4}-4 \frac{1}{4}$ lin. $\delta$.

The elytra are broad at the apex, and truncate, with each angle briefly spinous; they are distinctly narrowed in the middle, a little widened behind, and narrowed again to the apex, more so in the $q$ than in the $\delta$. The basal sulphur-yellow vitta of the elytra is very variable in form, and is sometimes only a rounded spot.

Hab.-Tapajos and Ega.

Found sometimes at flowers, and sometimes hovering in numbers over the trunks of felled trees.

\section{Agaone molorchoides.}

Rhinotragus molorchoides, White, Cat. Longic. Brit. Mus. p. 200.

" R. gracilis, luteus; capite, thoracis macula magna irregulari transversa, elytrorum marginibus nigris ; antennis nigris, segmentis 8 ultimis basi pallidis ; elytris vitreis." (White.)

Long. $3 \frac{1}{2}$ lin. $\delta$ $q$.

The elytra are much narrowed, and are slightly dehiscent; the apex obliquely truncate, with the angles scarcely produced; the form of the elytra, and their glassy discs, show an approach towards Odontocera.

Hab.-River Tapajos; on flowers. 


\section{Agaone colon, n. sp.}

Gracilis, testaceo-fulva, antennis, maculis duabus thoracis, et vitta laterali abbreviata elytrorum nigris; antennis articulis basi testaceis ; thorace elongato, lateribus paululum rotundato, grosse reticulato-punctato; elytris angustatis, dehiscentibus, apice recte truncatis, supra lateribus dense et disco sparsim punctatis; femoribus supra (posticis apice), tibiisque apice nigris.

Long. 4 lin. $\sigma^{\pi}$.

Hab.-Pará.

\section{Agaone malthinoides, n. sp.}

Tenuis, linearis, testaceo-flava, aureo-tomentosa, vertice maculaque transversa thoracis nigris; hoc sparsim grosse punctato, spatio dorsali lævi; elytris linearibus, haud attenuatis, grosse et dense punctatis, purpureofuscis, fascia ante-apicali testacea ; antennis corpore multo brevioribus, fuscis, articulis basi testaceis ; pedibus annulo femorali, tibiisque apice fuscis ; abdomine apice nigro.

Long. 3 lin. $\delta$ o

Hab.-Ega; on flowers.

\section{Agaone ruficollis, n. sp.}

Tenuis, linearis, nigra, thorace læte rufo, grosse sparsim punctato; elytris medio angustatis, utrinque carina abbreviata laterali, passim grosse punctatis, apice oblique truncatis, basi fulvis; antennis articulis basi, femoribus basi, tibiisque apice flavo-testaceis.

Long. 3 lin.

Hab.-Ega; on flowers.

\section{Genus Ommata.}

White, Cat. Longic. Brit. Mus. p. 194; Lacord. Gen. viii. 502.

Distinguished from the allied genera by the length (longer than the body in the $\delta^{\hat{}}$ ) and clavate form of the antennæ, by the long cylindrical thorax, and elongate hind legs. 


\section{Ommata aurata, n. sp.}

Viridi-aurata, metallica, dense fortiter (thorace rugose) punctata; elytris haud angustatis, basi excepta cæruleis; abdomine segmentis 2-4 cupreo-aureis splendidis; antennis nigris ; pedibus chalybeis.

Long. 5 lin. + .

Hab.-Villa Nova.

I found one example only of this beautiful species.

\section{Ommata smaragdina, n. sp.}

Gracilis, læte viridi-cyanea, elytris macula magna humerali aurantiaca et vitta laterali violacea ; capite rugosopunctato; thorace antice angustato, supra transversim rugoso-punctato; elytris apice oblique truncatis, angulo externo spinoso, supra passim dense punctatis ; antennis piceo-violaceis, basi pedibusque chalybeis.

Long. 5 lin. $\delta$

A still more richly-coloured species than 0 . aurata. One example.

$$
\text { Hab.-Ega. }
$$

\section{Genus Odontocera.}

Serville, Ann. Soc. Ent. Fr. 1833, p. 546; Lacord. Gen. viii. 503 .

\section{Odontocera chrȳsostetha, n. sp.}

Gracilis, melleo-flava, subtus aureo-pubescens; capite grosse crebre punctato; thorace cylindrico, dorso paulo longitudinaliter elevato, grosse et dense punctato, nigro 4-maculato vel bi-vittato; elytris longitudine corporis, paulo attenuatis, apice recte truncatis, disco politissimis, lateribus dense punctatis, sutura marginibusque (apice excepto) nigris; antennis piceo-rufis, nigro-maculatis; femoribus anticis supra nigro-lineatis, posticis medio nigro-annulatis; abdomine vespiformi.

Long. 6-6 $\frac{1}{2}$ lin. \& $q$.

Hab.-Pará and Ega. 


\section{Odontocera poecilopoda.}

White, Cat. Longic. Brit. Mus. p. 191.

"Nigra, elytris vitreis pallidis nigro-marginatis; abdominis basi subtus et apice pallidis; pedibus nigris, femorum tibiarumque basi alba; tibiis posticis pilis nigris hirtis.” (White.)

Long. $5 \frac{1}{2}$ lin. $\delta$.

The above description applies only to the $\delta$. In the of the abdomen is wholly testaceous-red; in both sexes it is much narrower than the metasternum, but in the $\delta$ it is exceedingly slender and linear in form. The hini tarsi in the + are pale testaceous. In both sexes the head and thorax are black, and the elytra are one-third shorter than the abajomen. The long black hairs of the hind tibiæ form a brush all round the joint from the middle to the apex.

Hab.-River Tapajos.

\section{Odontocera dispar, n. sp.}

0 . poecilopodae valde affinis; $\delta$ differt solum vitta laterali elytrorum ante apicem desinente; $q$ valde diversa, thorace fulvo, macula dorsali postica nigra; abdomine testaceo-fulvo, segmento 2ndo macula laterali nigra; tarsis omnibus flavis.

Long. $4 \frac{1}{2}-5 \frac{1}{2}$ lin. $\delta$ \& .

Hab.-Ega; abundant.

\section{Odontocera cinctiventris, n. sp.}

Minus elongata, nigra; capite grosse punctato, nitido; thorace breviori, postice angustiori, rotundato, æqualiter convexo, dense reticulato-punctato, marginibus antico et postico lineaque curvata laterali aureo-tomentosis; scutello aureo-tomentoso ; elytris abdomine vix brevioribus, grosse et dense punctatis, medio utrinque flavo vitreo, vix punctulato; abdomine vespiformi, segmento basali rufo, reliquis argenteo-marginatis; pedibus nigris, femoribus tibiisque basi testaceis, femoribus gradatim incrassatis.

Long. 4 lin. ( $\delta$ ?).

Hab.-Ega and Tapajos. 


\section{Odontocera parallela.}

White, Cat. Longic. Brit. Mus. p. 189.

"Pallide flava; antennis nigro-annulatis; thoracis dorso lineis duabus parallelis nigris; elytris apice angustatis, singulis linea marginali nigro-fusca; pedibus posticis subhirsutis, femoribus tibiisque apice fusconigris." (White.)

Long. $3 \frac{1}{4}$ lin. $\delta$ $~$.

The sexes, which I took in copulâ, do not differ in colour, and very little in the length of the antennæ, or form of abdomen. The antennæ are scarcely those of the typical Odontocerce, being slender, with the 7th-11th joints shortened and thickened, and not at all serrate; they are, however, even in the $\delta$, decidedly shorter than the abdomen, which character separates the species from Ommata, while the thickened apices distinguish it from Agaone, to which the species bears some resemblance. The elytra, however, are shorter by one-fourth than the abdomen, and have vitreous discs. The hind femora are abruptly clavate.

Hab.-River Tapajos.

\section{Odontocera mellea.}

White, Cat. Longic. Brit. Mus. p. 188.

"Melleo-flava, antennis nigro-annulatis; elytris corpore multo brevioribus, basi punctato, membranaceo, tunc vitreo, apice attenuato nigro; abdomine subtus medio nigro." (White.)

Long. $5 \frac{1}{4}$ lin. $\delta$.

White's description applies only to the $\delta$; the $ᄋ$ is totally different in coloration, being sooty-black, with the head and antennæ fulvous, spotted with black, the legs dusky, with the middle part of the femora pitchyred, and the apex of the abdomen yellowish. The abdomen, in most examples of the $\delta$, is black from the base, with the apex yellow, and the hind femora are black at the base.

The antennæ, in this species, are perfectly filiform, being neither thickened nor serrate towards the apex. 
The elytra are shorter by one-third than the abdomen, and widely dehiscent at the suture; the vitreous part does not reach to near the base, which is thickly punctured; the femora are gradually but strongly clavate.

Generally distributed throughout the Amazons; flying about branches of newly-felled trees.

\section{Odontocera punctata.}

Stenopterus punctatus, Klug, Nov. Act. Ac. Cæs. L. C. Nat. Cur. xii. 471 , pl. xliv. f. 4.

Nigra, thorace supra læte rufo-coccineo, crebre reticulato-punctato, femoribus posticis basi albo-testaceis; antennis incrassatis et subserratis; pedibus posticis valde elongatis, femoribus clavatis; elytris abdomine triente brevioribus, valde dehiscentibus, disco vitreo-flavis.

Long. $4 \frac{1}{2}$ lin.

Hab.-River Tapajos.

\section{Odontocera ornaticollis, n. sp.}

Nigra, læte aureo-tomentosa, antennis pedibus abdomineque testaceo-rufis; thorace magno, ovato, postice multo angustato, supra reticulato-punctato, margine antico et vittis quatuor antice abbreviatis læte aureotomentosis; elytris abdomine paulo brevioribus, angustis, mox pone scutellum dehiscentibus, fulvis, vitreis prope basin, fascia obliqua et margine laterali nigris.

Long. 6 lin. $\delta$.

Hab.-Santarem; at flowers. A superb species; the hind femora are very gradually clavate.

\section{Odontocera furcifera, $\mathrm{n} . \mathrm{sp}$.}

Robusta, flava, nigro-setosa, antennis abdomine pedibusque testaceo-rufis; thorace transversim ovato, litura furcata basi annexa maculaque laterali nigris; elytris abdomine paulo brevioribus, a medio abrupte attenuatis, disco flavo-vitreis, marginibus rufis, basin versus nigris, prope scutellum macula obliqua nigra; antennis brevibus, ab articulo 3io incrassatis ; pedibus posticis robustis, longe hirsutis, femoribus valde haud abrupte clavatis.

Long. 6 lin. $q$.

Hab.-River Tapajos. 


\section{Odontocera triliturata, n. sp.}

Flava, vertice fascia nigra; antennis apicem versus incrassatis et serratis, testaceo-rufis; thorace breviter cylindrico, crebre grossissime punctato, marginibus antico et postico, vitta dorsali et fascia mediana (vittam dorsalem haud attingente), nigris; elytris abdomine brevioribus, apicem versus dehiscentibus, flavis, dorso vitreis, sutura marginibusque fuscis, macula sub-basali prope humeros nigra; pedibus testaceo-rufis, femoribus basi albo-testaceis, abrupte clavatis.

Long. 5 lin. $q$.

Hab.-Pará.

\section{Odontocera fasciata.}

Necydalis fasciata, Oliv. Ent. No. 74, p. 10, pl. i. f. 9.

Odontocera chrysozone, White, Cat. Longic. Brit. Mus. p. 192, pl. v. f. 5 .

White gives the reference to Olivier's figure with a mark of doubt; but on comparing the description as well as the figure, there can be no uncertainty about his species being the same.

It is generally distributed throughout the Amazons, and not uncommon in the dry season, at sweet-smelling flowers. Like all the other species of these beautifully varied and interesting little creatures, it flies nimbly from flower to flower, deceiving the eye of the beholder by its strong resemblance to a wasp.

\section{Odontocera compressipes.}

White, Cat. Longic. Brit. Mus. p. 191.

"Lutea; capite flavo, gula mento et vertice nigris; antennis ferrugineis articulis 1 et 2 intus nigro lineatis; thoracis margine antica et annulo transverso, in dorso crassiores, nigris ; elytris vitreis luteis, basi scabris nigro variegatis, apice oblique truncatis ; tibiis posticis apice subdilatatis nigris hirtulis." (White.)

Long. $5 \frac{1}{2}$ lin. $\delta$ 우. 
White's description is drawn up from a female specimen. The $\delta$ differs in having a narrow black margin to the vitreous central part, which is quite continuous, except for a small space at the apex. The elytra are a little shorter than the abdomen, and dehiscent from the middle; the femora are abruptly and strongly clavate; the antennæ are but very slightly thickened towards the apex, almost filiform. The species, however, is very closely allied to O.fasciata, in which the antennæ are very strongly thickened. It is still more closely related to O. triliturata, in which the hind femora have no brushlike hairs.

Hab.-Ega, flying about dead trees; also Tapajos.

\section{Odontocera simplex.}

White, Cat. Longic. Brit. Mus. p. 189.

"Nigra, punctata ; elytris elongatis vitreis pallidis, margine late sutura anguste nigris; femoribus pedum duorum posticorum basi pallidis; tibiis posticis gracilibus nudis ; antennis nigris, articulis $5-8$ basi pallidis." (White.)-

Long. 4 lin. $\delta$.

The antennæ from the fifth joint are dilated, compressed, and serrate. The elytra are shorter than the abdomen, dehiscent, and sublinear.

Hab.-Pará.

\section{Odontocera cercerina, n. sp.}

Postice, attenuata, nigra, opaca; capite dense punctato, fronte lineis duabus aureo-tomentosis; antennis brevibus, rufo-piceis, versus apicem valde incrassatis; thorace elytris latiori, rotundato-quadrato, haud profunde sed dense punctato, nigro, opaco, marginibus antico et postico aureo-tomentosis; elytris extus mox pone humeros valde attenuatis, sutura dehiscentibus, abdomine paulo brevioribus, apice subacutis, supra vitta valde curvata abbreviata pallido-vitrea, pone hanc macula transversa alba, plaga magna triangulari circum-scutellari nigra opaca grosse punctata, reliquis nigris opacis, margine basali aureotomentoso ; corpore subtus nigro opaco, pectore utrinque 
fasciis duabus et abdomine vittis quatuor albo-tomentosis ; pedibus rufo-piceis, posticis elongatis, femoribus gradatim clavatis, tibiis apicem versus incrassatis, pilosis.

Long. $3 \frac{1}{2}$ lin. 오.

Hab.-Pará and Ega.

\section{Odontocera bisulcata, n. sp.}

Minus elongata, nigra, nitida; capite rufo-piceo, rostro elongatissimo; antennis brevibus, apicem versus incrassatis et serratis, rufo-piceis ; thorace oblongo, lateribus rotundatis, supra late bisulcato, grossissime sub-confluenter passim punctato ; elytris abdomine paululum brevioribus, gradatim angustatis, apice oblique truncatis, toto disco a basin usque ad apicem lævissimo, vitreo, vittam abbreviatam testaceo-albam includente, marginibus grosse punctatis; pedibus omnibus brevibus, robustis, femoribus fortiter clavatis, nigris, tibiis posticis incrassatis, haud pilosis, his tarsisque læte fulvis.

Long. 5 lin.

A remarkable species, which, from the inequalities of the thorax, might be considered to belong to Acyphoderes, but which differs from that genus in the elongate rostrum; in the last-named feature it exceeds all other species of Odontocera.

Hab.-River Tapajos.

Genus Isthmiade.

Thomson, Syst. Ceramb. p. 166; Lacord. Gen. viii. 504.

The striking resemblance which the species of this genus bear to species of Bracon (Fam. Ichneumonida) is increased by the filiform prolongation of the abdomen in the $q$, which imitates the ovipositor, and by the yellow and black wings.

\section{Isthmiade iehneumoniformis, $\mathbf{n} . \mathbf{s p}$.}

Nigra, nitida, elytris testaceo-flavis, pectore abdomineque (apice excepto) rufis; pedibus testaceo-rufis, femoribus posticis late fusco-annulatis, tibiis apice tarsisque fuscis; alis flavis, fascia apiceque nigris. 
Long. 5-7 lin. \& $\$$.

Hab.--Ega.

The posterior coxæ are black, and the breast spotted on the sides with black in some examples. The species has a most deceptive analogy to species of Bracon. It flies nimbly over decaying branches of felled trees.

Stenopterus braconides (Perty) belongs to this genus. It has recently been sent home by Mr. Rogers from Minas Geraes.

\section{Genus Phygopoda.}

Thomson, Syst. Ceramb. p. 164; Lacord. Gen. viii. 509.

Distinguished by its long and slender form, short muzzle, and very elongate and clavate hind femora, the tibiæ tufted with long black hairs. The following species agree with the definition as given by Lacordaire, but I am unacquainted with the typical species, Phygopoda fugax of Thomson.

\section{Phygopoda albitarsis.}

Stenopterus albitarsis, Klug, Nov. Act. Ac. Cæs. L. C. Nat. Cur. xii. 475, pl. xliv. f. 12.

Nigro-chalybea, pectore et annulis abdominis argenteotomentosis ; thorace nudo, plagis tribus politis elevatis, interstitiis grosse punctatis; elytris apicem segmenti primi abdominis attingentibus, abrupte attenuatis, acuminatis, plaga discoidali albo-testacea vitrea; pedibus posticis longissimis, tibiis nigro-scopariis, tarsis posticis albis.

Long. $4 \frac{1}{2}-7$ lin. \& $\$$ 우 .

Hab.-Ega ; also Tapajos.

Sometimes in great abundance at sweet-smelling flowers, and looking like a large Culex.

\section{Phygopoda subvestita.}

Odontocera subvestita, White, Cat. Longic. Brit. Mus. p. 190.

Melleo-flava, aureo-tomentosa; capite nigro, dense punctato; antennis fuscis, basi flavo-testaceis; thorace 
dense aureo-tomentoso, plagis tribus parvis discoidalibus elevatis politis ; elytris apicem segmenti primi abdominis attingentibus, abrupte attenuatis, obtuse acuminatis, melleo-flavis, disco vitreo concolori, marginibus prope basin fuscis; pedibus flavis, tarsis fuscis, femoribus posticis valde elongatis, gradatim clavatis, clava melleo-flava, tibiis posticis apice nigro-scopariis.

Long. 4-6 lin. of $q$.

Resembles Ph. albitarsis closely in form, in the small thorax and subulate elytra; but differs in the less abruptly clavate hind femora. It mimics a pale species of bee of the genus Melipona, even to the black hairy tufts of the hind tibiæ.

Hab.-River Tapajos.

\section{Genus Acyphoderes.}

Serville, Ann. Soc. Ent. Fr. 1833, p. 549; Lacord. Gen. viii. 505 .

\section{$\checkmark$ 1. Acyphoderes Olivieri.}

Necydalis abdominalis, Oliv. Ent. No. 74, p. 8, pl. i. f. 5 (?).

Niger, sericeo-tomen tosus; thorace oblongo-ovato, dorso depresso, lineis elevatis tribus, interstitiis aureo-tomentosis; elytris apicem segmenti ventris secundi attingentibus, subulatis, flavo-testaceis, vitreis, macula suturali pone scutellum marginibusque punctatis nigris, his juxta humerum lineolam testaceam includentibus; pectore argenteo, abdomine rufescente, sparsim griseo-piloso; pedibus anticis et intermediis nigris, femoribus crassis, basi et apice et tibiis lineis testaceis; pedibus posticis fulvo-rufis.

Long. $8 \frac{1}{2}$ lin. $\delta$ o $q$.

Closely allied to the common Brazilian A. aurulentus; differs in its slenderer form, black head, thorax, breast, and four anterior legs, and in the red untomentose abdomen. It agrees well with Olivier's description of N. aldeminatis, but differs from his figure in the much longer and subulate elytra. If we might assume that the figure is incorrect in this respect, the species would be the one described by him.

Hab.-River Tapajos; also Cayenne, Peru, \&c. 
2. Acyphoderes odyneroides.

White, Cat. Longic. Brit. Mus. p. 196, pl. v. f. 3.

Angustatus, niger ; thorace oblongo-ovato, costis tribus elevatis grosse punctatis, interstitiis aureo-tomentosis; elytris apicem segmenti ventris tertii attingentibus, attenuatis, valde dehiscentibus, apice acuminatis, pallide testaceo-fulvis, vitreis, margine prope humeros fusco, haud profunde punctato; abdomine vespiformi, cinctubus quatuor flavis; pedibus gracilioribus, femoribus clavatis.

Long. 7 lin. $\delta$ o ㅇ.

Found on the flowers of a low tree called Pitomba, and bears the most deceptive resemblance to a species of wasp seen on the same flowers. I was never sure whether I had captured the beetle or the wasp, until I had closely examined the insect in the bottom of the net.

Hab.-Santarem.

\section{Genus Tomopterus.}

Serville, Ann. Soc. Ent. Fr. 1833, p. 544; Lacord. Gen. viii. 509 .

Distinguished from Odontocera by the short subquadrate elytra, which do not pass the level of the posterior coxæ ; and from Acyphoderes by the same character, and by the convex closely punctured thorax.

\section{Tomopterus obliquus, n. sp.}

T. staphylino valde affinis, differt elytris prope suturam oblique truncatis. Niger, opacus ; antennis rufescentibus, fusco-maculatis ; thorace grosse reticulato-punctato, marginibus antico et postico fasciaque mediana medio interrupta aureo-tomentosis; elytris brevibus, extus et apice rotundatis, prope suturam oblique truncatis, basi fascia rufescente, disco linea obliqua flava; scutello nigro, apice aureo-tomentoso; pectore utrinque aureo-bifasciato, abdominis segmento primo rufo, reliquis aureo-marginatis ; pedibus rufescentibus, femoribus basi albo-testaceis.

Long. $3 \frac{1}{2}$ lin. $\delta$.

Hab.--River Tapajos. 


\section{Tomopterus bispeculifer.}

Odontocera bispeculifera, White, Cat. Longic. Brit. Mus. p. 190.

Niger; thorace rotundato, grosse reticulato-punctato, margine postico scutelloque aureo-tomentosis; elytris apice rotundatis nec truncatis, grosse punctatis, disco macula oblonga sub-obliqua flavo-testacea vitrea; corpore subtus nigro, nitido, epimeris aureo-tomentosis, segmento ventris primo interdum $(q)$ rufo ; pedibus nigris, femoribus posticis interdum ( $(\delta)$ albo-testaceis.

Long. $5-6 \frac{1}{2}$ lin. $\delta$ o .

Hab.-River Tapajos.

\section{Tomopterus larroides.}

White, Cat. Longic. Brit. Mus. p. 177.

Brevis, robustus; thorace valde transverso, convexo, lateribus rotundatis, piloso, punctato, opaco; elytris brevibus, apice recte truncatis, extus valde rotundatis, vitta obliqua obscure flava; abdominis segmentorum marginibus flavo-pilosis; femoribus posticis gradatim incrassatis, supra valde arcuatis.

đ. Supra niger, alisque nigris.

\%. Supra thorace medio flavescente, elytris lateribus castaneis, alis fulvis.

Long. 3-4 lin. $\delta$ o ㅇ.

Abundant once at flowers; closely resembles a small bee of the genus Megachile.

Hab.-Santarem.

\section{Epimelitta, nov. gen.}

Tomoptero affinis, differt corpore toto piloso, elytris abdominis basin attingentibus, apice valde attenuatis, subacuminatis. Rostrum breve, latum. Antennæ paullo incrassatæ, serratæ. Thorax brevis, valde transversus, convexus, hirtus. Tibiæ posticæ longe pilosæ.

The tapering apices of the elytra, widely dehiscent at the suture, and the pilose body and limbs, distinguish this genus from Tomopterus. In facies the species bear very 
little resemblance to any of the other genera, and, in fact, remind one more of bees of the Melipona group.

Molorchus scoparius, Klug, Nov. Act. Ac. Cæs. Nat. Cur. xii. 469 , pl. xliv. f. 2 , belongs to this genus. It is stated to be found at Cametá, on the Tocantins, where I collected for two months, but did not meet with it.

\section{Epimelitta meliponica, n. sp.}

Obscure fulva, densissime fulvo-pilosa, abdomine fuscotestaceo, nudo, nitido, apice segmenti primi aureo-marginato ; elytris fulvo-testaceis, nitidis, basi plaga communi nigra punctata, pilis rufis elongatis dense marginata; femoribus et tibiis posticis pilosis, his intus ante medium et extus versus apicem dense nigro-hirsutis; thorace brevi, lato, dense grosse punctato, nigricante, dorso crista pilorum nigricantium.

Long 6 lin. $q$.

Hab.-Ega.

Flying about decaying trees. Not distinguishable from a common species of Melipona when on the wing.

\section{Epimelitta rufiventris, n. sp.}

Nigra, abdomine rufo, opaco, griseo- sericeo, segmento primo tomento griseo dense marginato; thorace subglobuloso, postice constricto, grosse punctato, dorso spatio transverso lævi nitido, nigro-hirsuto, dorso antico canopubescenti ; elytris vitta sub-obliqua a basi ad apicem albo-testacea vitrea, intus vitta nigro-velutina marginata, plaga scutellari nitida; pedibus piceo-rufis, griseopilosis, femoribus posticis infra barbatis, tibiis intus et extus longe griseo-hirsutis.

Long. $6 \frac{1}{2}$ lin. $q$.

Hab.-Ega; on the trunk of a dead tree.

\section{Genus Æchmutes.}

Bates, Entom. Monthly Mag. iv. 23 (1867) ; Lacord.

Gen. viii. 511.

(Charac. emend.). Facies Lycorum (Fam. Lycidarum). Corpus oblongum, depressum, postice dilatatum, elytris 
carinatis, nigris, ochreo-fasciatis. Caput Odontocerce et Rhinotragi, rostro elongato. Thorax antice angustatus, æqualis, haud constrictus. Antennæ breves, medio valde dilatatæ, articulis subserratis, tertio brevissimo transverso. Pedes breves; femora gradatim clavata; tarsi breves. Coxæ anticæ subglobosæ, exsertæ, extus haud angulatæ; acetabula intermedia late aperta; prosterno et mesosterno inter coxas arcuatis.

A re-examination of my specimen of this curious insect confirms the supposition I formerly expressed, that it belongs to the Rhinotragina; the structure of its sternal pieces agreeing with the definition of the group, as given by Lacordaire.

\section{Achmutes lycoides, Bates, l. e.}

Depressus, nudus, opacus, testaceo-rufus, antennis nigris ; thorace strigis duabus utrinque nigris, usque ad oculos extensis ; elytris macula magna communi pentagona prope basin quartaque parte apicali nigris; tarsis tibiisque nigris, femoribus testaceis, in medio nigris; supra totus creberrime punctatus; elytris linea elevata ab humeris fere ad apicem extensa, hoc late undulatim truncato, angulis truncaturæ ambobus spinosis.

Long. $4 \frac{1}{2}$ lin. $q$.

Hab.-Ega.

\section{Genus Pandrosos.}

Bates, Entom. Monthly Mag. iv. 23 (1867); Lacord. Gen. viii. 510.

Corpus gracile, tenue; rostro quam in Rhinotrago breviori et latiori. Antennæ ( $q$ ) longitudine corporis, apicem versus crassiores, serratæ; articulus 3ius 4to duplo longior. Thorax elongatus, cylindricus. Elytra linearia, haud angustata, sed pygidium haud tegentia, apice oblique truncata, angulo externo dentato; supra plana, grosse punctata, carina laterali obtusa a medio ad apicem. Pedes elongati, tenues; femora longe pedunculata et clavata; tarsi postici articulo primo reliquis conjunctis longiori. Coxæ anticæ conicæ, exsertæ, extus haud angulatæ; acetabula intermedia extus perparum aperta. 
1. Pandrosos exilis.

Rhinotragus exilis, White, Cat. Longic. Brit. Mus.

$$
\text { p. } 201 .
$$

Linearis, tenuis, fulvo-testacea ; elytris passim punctatis; antennis fuscis; femoribus posticis apice, tibiis tarsisque mediis et posticis, nigro-fuscis.

Long. 3 lin. $q$.

The eyes are widely distant in front and on the crown, and prominent.

Hab.-Villa Nova, Amazons; on flowers.

\section{Sub-fam. Callichromatina.}

\section{Genus Callichroma.}

Latreille, Règne Anim. (ed. 1) iii. 341 ; Lacord. Gen. ix. 15 .

1. Callichroma suturale.

Cerambyx suturalis, Fabricius, Sp. Ins. i. 212 ; Oliv. Ent. No. 67 , p. 25 , pl. vi. f. 40 .

Nigrum, subtus paulo virescens, supra velutinum, elytris vitta suturali alteraque discoidali (postice co-euntibus) cupreo-aureis ; pedibus nigris, tibiis posticis dilatatis et compressis.

Long. 10-19 lin. $\delta$ o .

Hab.-Pará and Tapajos.

\section{Callichroma porphyrogenitum, n. sp.}

Magnum, robustum, subtus viride, dense argenteovelutinum; supra capite thorace et scutello violaceis, hoc nigro-bivittato, elytris læte cyaneis, ad latera violaceis, utrinque vitta discoidali prope suturam nigro-velutina; pedibus nigris, femoribus basi grosse punctatis, posticis sericeis, tibiis dilatatis et compressis.

Long. 1 un. 9 lin. $\delta$.

A magnificent species, with the hind tibiæ dilated in the same manner as $C$. suturale. The legs, however, are 
more robust, and the tarsi much broader. The head, thorax, and scutellum are of a beautiful violet colour, and the ground-colour of the elytra is of greenish-blue metallic lustre graduating into violet on the sides.

Hab.-Manaos, Rio Negro.

One example only.

\section{Callichroma brachiale, n. sp.}

C. vittato* (Fabr.) affine; subtus viridi-æneum, argenteo-griseo-sericeum; supra capite et thorace cyaneis splendidis, hoc maculis duabus velutinis violaceis; scutello viridi-æneo, splendido ; elytris nigro-velutinis, apice violaceis, sutura anguste vittaque discoidali a humero incipiente viridibus; pedibus nigris, femoribus quatuor anticis rufis, basi et apice fuscis, tibiis posticis $\delta$ ut in C. vittato compressis at minus dilatatis.

Long. 13 lin. ơ.

Hab.-River Japurá, near Ega.

One example.

\section{Callichroma rugicolle.}

C. rugicollis, Guérin, Icon. R. A. iii. 220.

C. assimilatum, White, Cat. Longic. Brit. Mus. p. 158.

I can perceive no difference between Pará specimens of White's $C$. assimilatum and Mexican examples of $C$. rugicolle. The species belongs to the group in which the hind tibiæ are only very slightly and very gradually dilated from base to apex. The colour is a brilliant metallic-green, silvery-gray-tomentose on the under surface, marked on the thorax with two short velvettyblack vittæ, and on the elytra by a similar vitta, extending from the middle of the base very nearly to the apex ; the sides of the elytra become gradually darker green and velvetty. The thorax is crossed throughout by fine rugæ, and the antenniferous tubers are longitudinally rugose. All the thighs are tawny-red.

* C. vittatum, described by Fabricius from Banks' collection, is a common South Brazilian insect, having the thighs red, the under-surface clothed with golden tomentum, and the suture generally with a golden tinge: the hind tibiæ are only slightly and gradually dilated from base to apex. 
Long. 7-10 lin. $\delta$ o 우 .

Hab.-Pará, Santarem, and Ega, on flowers; also Cayenne, Mexico, and probably widely distributed in Tropical America.

\section{Callichroma aureotinctum, n. sp.}

C. rugicolli valde affine, paulo robustius, magis aureoviride, præcipue elytris apice læte aureis ; capite viridiaureo, splendido, sparsim punctato, tuberibus antenniferis haud strigosis; thorace multo minus striato.

Long. 7-10 lin. \& o .

Hab.-Santarem, Amazons; on flowers.

Possibly only a variety of $C$. rugicolle, found on the same trees in company.

\section{Callichroma ocreatum, n. sp.}

C. rugicolli affine, majus, tarsis omnibus apiceque tibiarum pallide fulvis; robustum, læte viridi-æneum, subtus argenteo-tomentosum; thorace transversim subtiliter strigoso, nigro-velutino bivittato; scutello splendido, aureo; elytris utrinque vitta dorsali nigro-velutina; femoribus rufis, tibiis (apice fulvo excepto) nigris, tarsis ochreo-fulvis.

Long. 13 lin. $\delta$ q .

Hab.-Lower Napo, near Pebas, Upper Amazons.

A score examples, all alike. 


\section{$2 \mathrm{BHL}$ Biodiversity Heritage Library}

Bates, Henry Walter. 1870. "XVI. Contributions to an Inset Fauna of the Amazon Valley (Coleoptera, Cerambycidæ)." Transactions of the Entomological Society of London 18, 243-335.

https://doi.org/10.1111/j.1365-2311.1870.tb01876.x.

View This Item Online: $\underline{\text { https://www.biodiversitylibrary.org/item/51073 }}$

DOI: https://doi.org/10.1111/j.1365-2311.1870.tb01876.x

Permalink: https://www.biodiversitylibrary.org/partpdf/10212

\section{Holding Institution}

Smithsonian Libraries

\section{Sponsored by}

Smithsonian

\section{Copyright \& Reuse}

Copyright Status: Public domain. The BHL considers that this work is no longer under copyright protection.

This document was created from content at the Biodiversity Heritage Library, the world's largest open access digital library for biodiversity literature and archives. Visit BHL at https://www.biodiversitylibrary.org. 